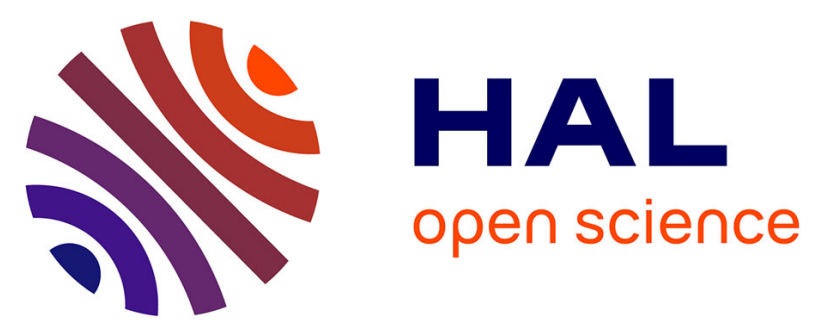

\title{
Early-Middle Holocene environmental changes and pre-Neolithic human occupations as recorded in the cavities of Jebel Qara (Dhofar, southern Sultanate of Oman)
}

Mauro Cremaschi, Andrea Zerboni, Vincent Charpentier, Rémy Crassard, Ilaria Isola, Eleonora Regattieri, Giovanni Zanchetta

\section{To cite this version:}

Mauro Cremaschi, Andrea Zerboni, Vincent Charpentier, Rémy Crassard, Ilaria Isola, et al.. Early-Middle Holocene environmental changes and pre-Neolithic human occupations as recorded in the cavities of Jebel Qara (Dhofar, southern Sultanate of Oman). Quaternary International, 2015, Green Arabia: Human Prehistory at the Cross-roads of Continents, 382, pp.264 - 276. 10.1016/j.quaint.2014.12.058 . hal-01829330

\section{HAL Id: hal-01829330 https://hal.science/hal-01829330}

Submitted on 4 Jul 2018

HAL is a multi-disciplinary open access archive for the deposit and dissemination of scientific research documents, whether they are published or not. The documents may come from teaching and research institutions in France or abroad, or from public or private research centers.
L'archive ouverte pluridisciplinaire HAL, est destinée au dépôt et à la diffusion de documents scientifiques de niveau recherche, publiés ou non, émanant des établissements d'enseignement et de recherche français ou étrangers, des laboratoires publics ou privés. 


\title{
Early-Middle Holocene environmental changes and pre-Neolithic human occupations as recorded in the cavities of Jebel Qara (Dhofar, southern Sultanate of Oman)
}

\author{
Mauro Cremaschi ${ }^{\text {a }}$, Andrea Zerboni a , Vincent Charpentier ${ }^{\mathrm{b}}$, Rémy Crassard ${ }^{\mathrm{c},}$, \\ Ilaria Isola ${ }^{\mathrm{d}}$, Eleonora Regattieri e, f, Giovanni Zanchetta ${ }^{\mathrm{d}, \mathrm{e}, \mathrm{f}, \mathrm{g}}$ \\ a Università degli Studi di Milano, Dipartimento di Scienze della Terra “A. Desio”, via L. Mangiagalli 34, I-20133 Milan, Italy \\ b Inrap, UMR 7041 'ArScAn', Maison de l'Archéologie et de l'Ethnologie, Nanterre, France \\ ' CNRS, UMR 5133 'Archéorient', Maison de l'Orient et de la Méditerranée, Lyon, France \\ ${ }^{\mathrm{d}}$ Istituto Nazionale di Geofisica e Vulcanologia, Via della Faggiola 32, I-56100 Pisa, Italy \\ e Dipartimento di Scienze della Terra, Università di Pisa, Via S. Maria 53, I-56126 Pisa, Italy \\ ${ }^{\mathrm{f}}$ Istituto di Geoscienze e Georisorse-C.N.R., Via Moruzzi 1, I-56100 Pisa, Italy \\ ${ }^{\mathrm{g}}$ Istituto di Geologia Ambientale e Georisorse-CNR, Area della Ricerca di Roma1 - Montelibretti, Via Salaria Km 29,300, Monterotondo, RM, Italy
}

\section{A R T I C L E I N F O}

\section{Article history:}

Available online 13 January 2015

\section{Keywords}

Holocene

Oman

Palaeoenvironment

Speleothems

Cave sites

Land shell accumulations

\begin{abstract}
A B S T R A C T
Numerous palaeoenvironmental and archaeological studies from southern Arabia (Yemen and Oman) have revealed strong relations between phases of human settlements and climate change linked to the Indian monsoon system. Analyses on speleothems, cave fills, lacustrine deposits and palaeo-mangroves have shown that during the Early to Mid-Holocene, a humid Optimum culminated around $9000-8000$ cal BP. New results on inland speleothems and cave sediments from the Jebel Qara (southern Oman) are crucial in our depiction of Early and Mid-Holocene climatic evolution and cultural dynamics of the region. These aspects are discussed here, based on new archaeological surveys, excavations, geoarchaeological and micromorphological studies, aiming to better understand connections with Terminal Pleistocene and Early Holocene autochthonous cultures of southern Arabia. Our results suggest that the final Pleistocene was marked by strong aridity, which promoted a widespread thermoclastism within rock shelter and deposition of aeolian sand; in contrast, the transition towards the Holocene is marked (since c. 12,000 cal BP) by a progressive increasing in environmental humidity, which permitted the formation of thick strata of peridesert loess. After this phase, the environmental humidity of the Jebel increased and permitted the existence of a large community of land snails; the latter were exploited by Early Holocene hunter-gatherers who lived in the rock shelters between c. 10,500-9500 cal BP and left consistent accumulations of land shells (escargotières). The maximum of Holocene humidity was reached between 9000 and $8000 \mathrm{cal} \mathrm{BP}$; regional aquifer were recharged and the deposition of calcareous tufa at the entrance of caves started, lasting up to c. $4500 \mathrm{cal}$ BP. C and O stable isotopes from calcareous tufa highlights, in accordance with several regional records, the progressive decline of the intensity of the Indian Ocean monsoon and the transition towards arid conditions. In this phase, the area was abandoned and archaeological communities possibly relocated along the coast of central and southern Oman, where they exploited the mangrove environment.
\end{abstract}

() 2015 Elsevier Ltd and INQUA. All rights reserved.

\section{Introduction}

The Early Holocene climatic (mostly precipitation regime) evolution in southern Arabia is now known thanks to studies of

\footnotetext{
* Corresponding author

E-mail address: remy.crassard@mom.fr (R. Crassard).
}

palaeolakes and speleothems in Yemen, Oman, Saudi Arabia and the United Arab Emirates (e.g., Fleitmann et al., 2003; Davies, 2006; Lézine et al., 2007; Parker, 2009). Furthermore, high-resolution oxygen isotope profiles of Holocene stalagmites from several caves in northern and southern Oman and Yemen (Socotra) recently published (Burns et al., 1998; Neff et al., 2001; Fleitmann et al., 2003, 2004, 2007, 2011) provide detailed information on Late Quaternary climatic fluctuations of southern Arabian 
Peninsula and western Indian Ocean. Palaeoclimatic data were also obtained from sand dunes, loess-like deposits, and paleosols (e.g., Nettleton and Chadwick, 1996; Wilkinson, 1997; Coque-Delhuille and Gentelle, 1998; Preusser et al., 2002; Parker et al., 2006; Pietsch and Kühn, 2009; Pietsch et al., 2010).

Early Holocene human occupation of south-east Arabian Peninsula is witnessed by lithic assemblages characterized by blade productions and the Fasad points, being considered as a lithic facies that still needs to be clearly defined (Charpentier, 2008; Charpentier and Crassard, 2013). The so-called Fasad points are characteristic Early Holocene tanged points made on elongated flakes or blades/bladelets are rarely found in stratigraphic contexts (e.g., Uerpmann et al., 2013). Nevertheless, they most often occur as surface finds, thus making it difficult to understand the relationships between climatic changes and cultural dynamics. The caves and the rock shelters that dot the wadis cutting the southern part of Jebel Qara, a massif facing the coast of Dhofar (southern Oman), provide an important opportunity to fill this gap as they include anthropogenic sediments of the Early Holocene hunter-gatherers occupations interlayered with breccias, loess, and calcareous tufa, which were the products of the local effect of the Early Holocene climatic changes. Geoarchaeological research previously performed in the area (Cremaschi and Negrino, 2002, 2005) was recently resumed and the results obtained are presented in this paper.

\section{Study region}

The region of Dhofar in south-western Oman, bordering the Hadramawt and Mahra regions of eastern Yemen, is a mountainous and plateau region, with one particular limestone massif (Fig. 1), which separates the coastal plain of Salalah from the Nejd Desert: the Jebel Qara (Cremaschi and Negrino, 2005), representing the continuation in Oman of the Yemeni Hadramawt plateau (Fig. 2). Jebel Qara's top is gently undulating and it reaches the maximum height of $\sim 850 \mathrm{~m}$ above sea level. From the geological point of view, the massif consists of late Cretaceous to Tertiary limestone (Platel et al., 1992). Geological strata are gently tilted to the North and crossed by systems of faults in the area above the Salalah coastal plain and immediately south of the Nejd Desert. Loess deposits occur along the northern fringe of the jebel and are similar to deposits described on the Yemeni Plateau and dated to the Early Holocene (Nettleton and Chadwick, 1996; Cremaschi and Negrino, 2005). A well developed karst net is present in the Jebel Qara massif and many rock shelters are located along the steep slopes in the southern part of the jebel (Platel, 1992; Hanna and Al-Belushi, 1996); many of them can be interpreted as inland notches (Shtober-Zisu et al., 2015). The southern margins of the Jebel Qara are connected to the present-day coastline of the Indian Ocean by an alluvial apron consisting of steep alluvial fans, composed of gravel-dominated sediments and dating mostly to the Upper Pleistocene (Platel, 1992; Hoorn and Cremaschi, 2004). At the foot of the fan extensive formations of beach rocks are present together with aeolian sand formations. These hang some meters (up to 3-4 $\mathrm{m}$ ) above the present day shore, suggesting the position of the sea level at the time of the maximum postglacial rebound (Pirazzoli, 1991). Alluvial fans toward the sea also delineate several fossil swamp basins, filled by organic matter-rich mud (Platel et al., 1992; Hoorn and Cremaschi, 2004; Cremaschi and Perego, 2008).

Today, southern Oman is a semi-arid land, with annual precipitations ranging from 200 to $600 \mathrm{~mm}$; most of them are concentrated between July and September (more than $80 \%$ ), when the monsoonal rain from the Indian Ocean reaches the region (Fleitmann et al., 2004). Jebel Qara forms a barrier against the summer monsoon. Rain supports shrubs and trees on the southern coastal side of the mountain; to the North, the plateau gradually becomes an arid steppe (Rogers, 1980; Sale, 1980), where overgrazing has recently enhanced the desertification process and soil loss (Sale, 1980a, 1980b; Rogers, 1980). On the contrary, during the Holocene the climate of the region, as of the entire Arabian Peninsula, greatly changed. In fact, high-resolution oxygen isotope curves of Holocene stalagmites from caves in northern and southern Oman and Yemen provided detailed information on climatic fluctuations of southern Arabian Peninsula (Burns et al., 1998; Fleitmann et al., 2003, 2004, 2007, 2011). These variations, controlled by the position of the Intertropical Convergence Zone (ITCZ) and dynamics of the Indian Ocean monsoon, are briefly reported. In the Early Holocene rapidly decreasing values of $\delta^{18} \mathrm{O}$ indicates a rapid northward displacement in the latitudinal position of the summer ITCZ and the associated monsoonal rainfall belt; while during the Middle to Late Holocene the summer ITCZ continuously migrated southward and monsoon precipitation decreased gradually in response to decreasing insolation (Fleitmann et al., 2004).

The Dhofar archaeological record for the Early Holocene is mainly characterized by surface sites, but also a few stratified (e.g., Zarins, 2001, 2013; Hilbert, 2013). The Early Holocene occupations of southern Oman, and more broadly of the whole southern Arabia, are in fact quite unclear, mostly known by blade productions, as well as tanged lithic projectiles (including Fasad points). Very little is known about these rare typological elements. It is even more difficult to define the origins and the development of the makers of such industries. While researchers have used different terms to refer to this chronological period such as Late Palaeolithic or Epipalaeolithic (e.g., Cremaschi and Negrino, 2002; Hilbert, 2013), a consensus has not yet been reached in the scientific community working in this area on how to call this pre-Neolithic period. Discoveries have been too sparse up to now to resolve this debate. The lack of a clear Upper Palaeolithic and the exact transition to fully
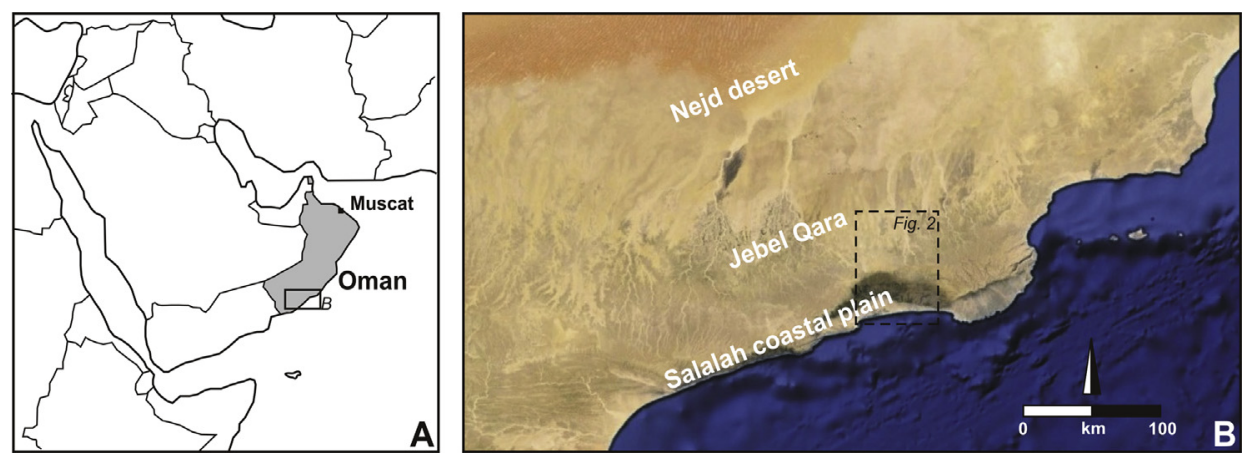

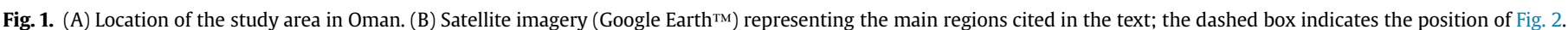




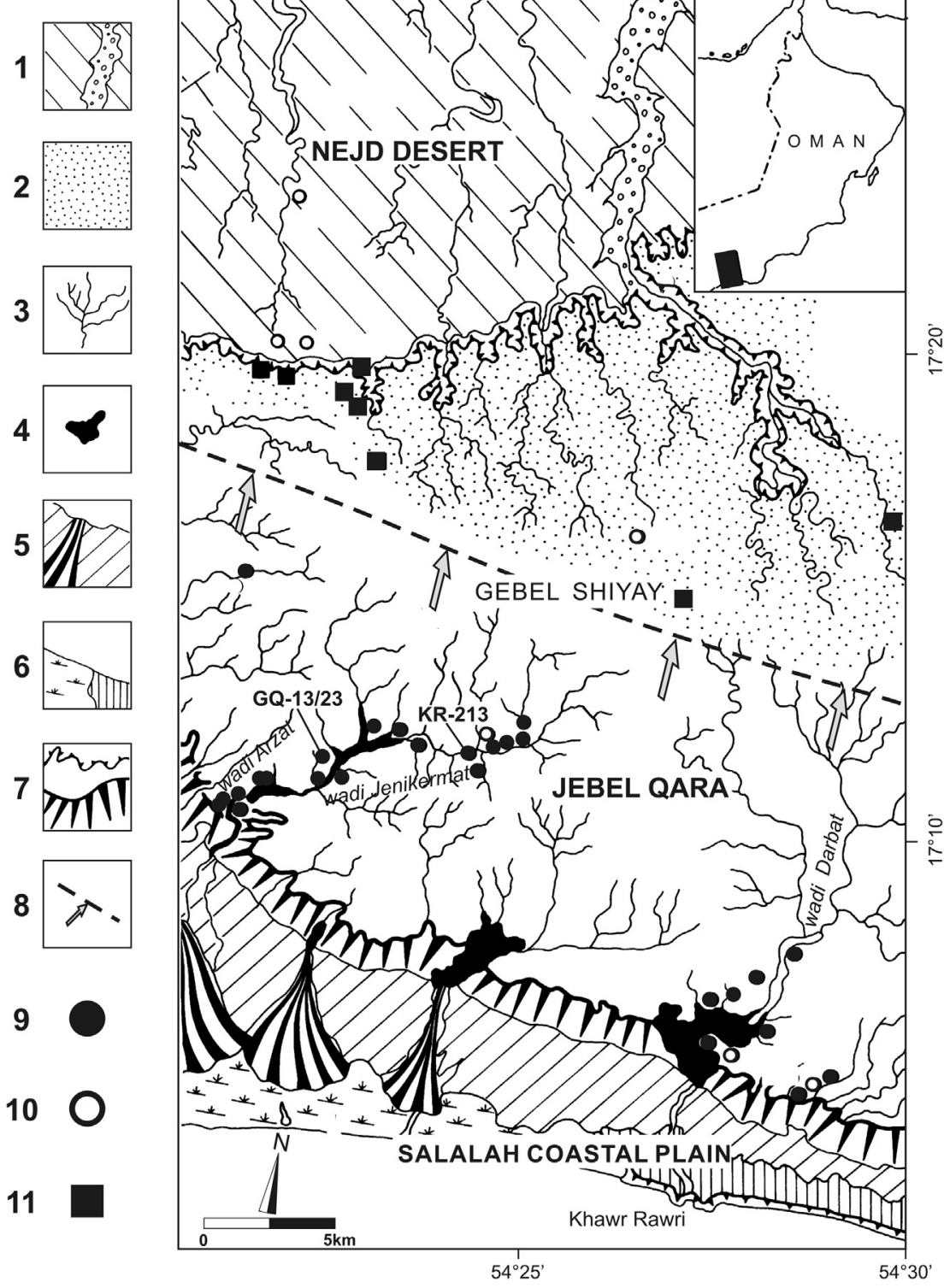

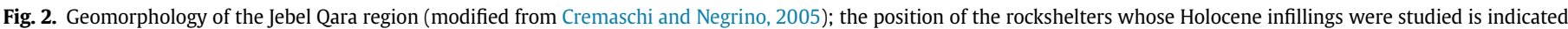

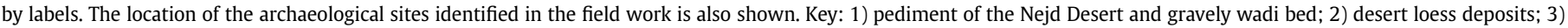

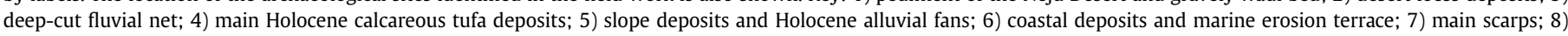

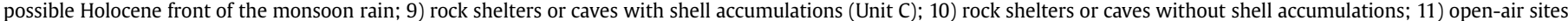
(see Cremaschi and Negrino, 2005).

neolithicized societies rendering it difficult to do so. The more recent sites dated to the Neolithic period (from c. 8000 cal BP) are mostly shell middens along the Omani coasts, with rich and consistent cultural material (e.g., Charpentier, 2008) and frequently linked to mangroves and lagoons (Berger et al., 2005, 2013). The lithic industries are well-known, with specific projectile point types, including trihedral and fluted points that are found in the broader southern Arabian Peninsula (Charpentier, 2004, 2008; Crassard, 2009).

\section{Materials and methods}

Beyond deposits related to their recent pastoral use, most of the Jebel Qara's cavities preserve an older sedimentary infilling. The latter occurs in most of the visited cavities with the same characteristics and consists, form the base to the top, of angular breccia, loess deposits and accumulations of land snails (including charcoal and lithic artifacts). Finally, the deposits are sealed by thick calcareous tufa in form of flowstones (Cremaschi and Negrino, 2005). During the field survey, preliminary test trenches were opened in the cavities KR-213 and GQ-13/23 to investigate the archaeological evidence and to collect samples for micromorphological analysis on the base deposits and geochemical analyses on calcareous tufa. Moreover, charcoal samples were collected and submitted to AMS- ${ }^{14} \mathrm{C}$ radiometric dating; the results of new dating and those reported in Cremaschi and Negrino (2005) are indicated in text and in Table 1 as uncal and cal BP; calibration is according to the IntCal13 curve (Reimer et al., 2013).

Thin sections from undisturbed blocks from the archaeological infilling at the bottom of the Jebel Qara caves (KR-213 and GQ-13/ 23) have been used to identify the stratigraphic sequenceforming processes and to infer the environmental and anthropogenic factors for sediments accumulation and post-depositional changes (e.g., Courty, 2001; Goldberg and Macphail, 2006; 
Cremaschi et al., 2014). Oriented and undisturbed blocks from the sediments below the flowstones were collected. Thin sections $(5 \times 9 \mathrm{~cm})$ were manufactured after consolidation according to standard methods (Murphy, 1986). Micromorphological observation under plane-polarized light (PPL), cross-polarized light (XPL), and oblique incident light (OIL) of sediment thin sections employed an optical petrographic microscope Olympus BX41 with a digital camera (Olympus E420). For the description and interpretation of thin sections, the reader should consider the terminology and concepts established by Bullock et al. (1985), Stoops (2003) and Stoops et al. (2010). Properties of samples detected by thin section analysis are summarized in Table 2.

Two different samples were collected from the same flowstone decoration (KR1 and KR3) outcropping from the roof of the KR-213 rock shelter and submitted for geochemical analyses. These samples were cut in the laboratory, put in resin and polished. From polished surfaces, samples for U/Th dating and stable isotope analyses (C and O) were collected. Solid prisms of ca. $200 \mathrm{mg}$ (ca. $3 \mathrm{~mm}$ wide along the lamina and $1 \mathrm{~mm}$ thick on growth axis) were used (e.g., Regattieri et al., 2014). Eight samples were taken for U/Th dating which was performed at the University of Melbourne (Victoria, Australia), following the method proposed by Hellstrom (2003). Correction for detrital Th content was applied using initial activity ratios of detrital thorium $\left[{ }^{230} \mathrm{Th} /{ }^{232} \mathrm{Th}\right]_{\mathrm{i}}$ of $1.50 \pm 1.50$. Results, indicated as years BP, are summarized in Table 3. Samples for stable isotope analyses were drilled using an air drill with a drill bit of $1 \mathrm{~mm}$. Average distance between samples of ca. $1.5 \mathrm{~mm}$. Stable oxygen $\left(\delta^{18} \mathrm{O}\right)$ and carbon $\left(\delta^{13} \mathrm{C}\right)$ isotope ratios were performed with a Gas Bench II (Thermo Scientific) coupled with an IRMS Delta XP (Finnigan Matt) at the Institute of Geosciences and Earth Resources of CNR in Pisa (Italy). Briefly, carbonate samples of ca. $0.15 \mathrm{mg}$ were dissolved in $\mathrm{H}_{3} \mathrm{PO}_{4}(100 \%)$ for one hour at $70{ }^{\circ} \mathrm{C}$ in sealed vials flushed with helium. The headspace gas $\left(\mathrm{CO}_{2}\right)$ is entrained in a helium stream, dried with 2 nafion gas dryer, purified by passing through a gas chromatographic column and then injected in the continuous flow isotope ratio mass spectrometer via an active open split. All the results were reported to the relative Vienna PeeDee Belemnite (VPDB) international standard. Sample results were corrected using the international standard NBS-19 and a set of 3 internal standards: two marbles, MOM and MS, and a carbonatite NEW12, previously calibrated using the international standards NBS-18 and NBS-19. Analytical uncertainty for replicated analyses of $\delta^{18} \mathrm{O}$ and $\delta^{13} \mathrm{C}$ were c. $0.15 \%$.

\section{Results}

\subsection{Description of the cave infillings and micromorphology of the deposits}

The entrance and the outer part of karst cavities and rock shelters, which are exposed at different heights along the slopes of

Table 1

Results of conventional and AMS $-{ }^{14} \mathrm{C}$ dating; calibrated age results are reported as years BC and BP. Calibration according to IntCal13 curve (Reimer et al., 2013).

\begin{tabular}{lllcll}
\hline \multirow{2}{*}{$\begin{array}{l}\text { Rock } \\
\text { shelter }\end{array}$} & Unit & Lab.-code & $\begin{array}{l}\text { AMS- }{ }^{12} \mathrm{C} \\
\text { age }(\mathrm{yr} B P\end{array}$ & \multicolumn{2}{l}{ AMS- ${ }^{12} \mathrm{C}$ age cal $2 \sigma$} \\
\cline { 5 - 6 } & & & & (yr cal BC) & (yr cal BP) \\
\hline GQ-13/23 & B & Poz-56575 & $10,040 \pm 50$ & $9848-9361$ & $11,798-11,311$ \\
GQ-13/23 & C & Poz-56576 & $9150 \pm 50$ & $8536-8276$ & $10,486-10,226$ \\
KR-213 & B & GX-24065 & $9130 \pm 290$ & $9142-7601$ & $11,092-9551$ \\
GQ-13/23 & C & Poz-56574 & $9010 \pm 50$ & $8300-7984$ & $10,250-9934$ \\
KR-108 $^{\text {a }}$ & B & GX-23159 & $8750 \pm 50$ & $7965-7603$ & $9915-9553$ \\
KR-213 $^{\text {a }}$ & C & GX-2470-AMS & $8720 \pm 60$ & $7953-7597$ & $9903-9547$ \\
\hline
\end{tabular}

${ }^{a}$ Radiocarbon dating from Cremaschi and Negrino (2005). the wadis of Jebel Qara, are systematically covered by calcareous tufa in shape of large flowstones, stalactites and stalagmites. Calcareous tufa accretion is today inactive and they are on the way to collapse and being dismantled; therefore, they are evidence of former higher precipitation in the area (Cremaschi and Negrino, 2005). The calcareous tufa flows cover and preserve a complex stratigraphic sequence composed from the base of angular breccia, aeolian dust and accumulations of land snails, which are associated to anthropogenic deposits. Lands snails and associated evidence of human activity (lithic industries and charcoal) have been found only inside the rock shelters and caves opening along the valley bottom, while they lack inside the cavities located to higher elevation along the slope of the wadis. In the latter type of rock shelter calcareous tufa lies directly on angular breccia and aeolian dust. The rock shelters discussed here, site KR-213 and GQ-13/23, are located along the Wadi Jenikermat and may be considered as the reference sequences for the region (Fig. 3).

The infilling of site KR-213 consists, from the bottom to the top of the sequence, of three main sedimentary Units (Figs. 3 and 4), A to $C$, sealed by a thick layer of calcareous tufa, Unit D (Cremaschi and Negrino, 2005). The lowermost Unit (A) is a clast-supported angular breccia, associated with intergranular sand. The breccia, derived from the fragmentation of the rock shelter vault, is composed of coarse and medium clasts organized in irregular, discontinuous, non-parallel planar layers that dip towards the mouth of the cave and have an abrupt contact with the underlying bedrock. The intergranular fine fraction is composed of rounded and sub-rounded sand-sized quartz, feldspar, and other mineral grains, interpreted as an aeolian input to sedimentation. The overlaying Unit B is a matrix-supported breccia, consisting of very few medium-sized angular fragments of limestone interbedded with brown massive loam. Few thin (about $2 \mathrm{~cm}$ ), discontinuous, dark brown archaeological layers, all rich in charcoal and flint artefacts, have been identified within this Unit. Cremaschi and Negrino (2005) have demonstrated that the fine fraction has a loess-like grain-size distribution, suggesting input of aeolian silt. A charcoal chunk from the upper part of this Unit permitted to date it at $9130 \pm 290$ uncal BP $(11,092-9551 \mathrm{cal} \mathrm{BP})$. The following Unit C consists of a high concentration of land snails dispersed in a silty matrix, often showing a clast-supported pattern; shells are arranged in discontinuous, nonparallel planar layers several centimetres thick. Unit $\mathrm{B}$ has been radiocarbon dated to $8720 \pm 60$ uncal BP (9903-9547 cal BP). The mollusc assemblage mostly includes Euryptyxis latireflexa and Revoilia dhofarense. These are generally complete specimens, which in some cases are broken and distributed on planar layers (Cremaschi and Negrino, 2005). These species are representative of mesophilous species, adapted to a dense grass cover and requiring wet conditions and vegetal cover (Wright, 1963; Wright and Brown, 1980). Finally, the uppermost Unit $A$ is a thick flowstone deposit sealed with stalagmites, descending from the roof of the shelter and covering the sedimentary fill. The calcium carbonate that formed the flowstones also deeply penetrated in the underlying stratigraphic sequence and most of the layers are moderately to strongly cemented.

The sedimentary infilling of cave GQ-13/23, discovered during the field season 2013 along the same wadi a few kilometres downstream of the KR-213 shelter, displays a rather similar stratigraphic sequence (Fig. 4). Unit A is not represented in the section investigated, while the Unit $B$, occurring at the base of the sequence, consists of thin and discontinuous layers of clast-to matrix-supported breccia. Unit $C$ is a particularly thick $(\sim 1 \mathrm{~m})$ and strongly cemented layers, constituted of gently deepening silty layers including a high concentration of land snails. It is interesting to notice that Unit B at site GQ-13/23 is intercalated with silty layers very rich in angular fragments of charcoal and flint artefacts 
Table 2

Essential micromorphological descriptions of samples representative for the four stratigraphic units composing the infilling of the rock shelters.

\begin{tabular}{|c|c|c|c|c|c|c|c|c|}
\hline Unit & Field interpretation & Mineral constituents & Biogenic constituents & Porosity & Microstructure & b-fabric & $\begin{array}{l}\text { c/f related } \\
\text { distribution }\end{array}$ & Pedofeatures \\
\hline A & $\begin{array}{l}\text { Clast-supported } \\
\text { angular breccia }\end{array}$ & $\begin{array}{l}\text { Dominant angular } \\
\text { fragments of limestone and } \\
\text { scarce to common quartz } \\
\text { and feldspar grains (sand } \\
\text { size) in a silty-clayey } \\
\text { micromass }\end{array}$ & - & $\begin{array}{l}\text { Common packing } \\
\text { voids and vughs }\end{array}$ & $\begin{array}{l}\text { Intergrain } \\
\text { microaggregate }\end{array}$ & Cristallitic & Gefuric to enaulic & $\begin{array}{l}\text { Common micrite coatings } \\
\text { on grains and } \\
\text { microaggregates, scarce } \\
\text { calcite pendent on rock } \\
\text { fragments; few calcite } \\
\text { nodules; few Fe-nodules; } \\
\text { very few clay papulae }\end{array}$ \\
\hline B & $\begin{array}{l}\text { Matrix-supported } \\
\text { angular } \\
\text { breccia and loess }\end{array}$ & $\begin{array}{l}\text { Common to scarce angular } \\
\text { fragments of limestone, } \\
\text { common silt-sized quartz } \\
\text { grains and few sand-sized } \\
\text { quartz grains in a clay } \\
\text { micromass }\end{array}$ & $\begin{array}{l}\text { Few to scarce } \\
\text { fragments of shells, few } \\
\text { concentrations of } \\
\text { angular charcoal } \\
\text { fragments; very few, } \\
\text { small angular } \\
\text { fragments of bone }\end{array}$ & $\begin{array}{l}\text { Common vesicular } \\
\text { voids, chambers, } \\
\text { and vughs; scarce } \\
\text { channels }\end{array}$ & $\begin{array}{l}\text { Spongy to } \\
\text { crumb }\end{array}$ & Cristallitic & $\begin{array}{l}\text { Spaced to open } \\
\text { porphyric }\end{array}$ & $\begin{array}{l}\text { Common micrite and } \\
\text { sparite coatings on voids, } \\
\text { scarce calcite pendent on } \\
\text { rock fragments; scarce } \\
\text { calcite nodules; } \\
\text { groundmass impregnated } \\
\text { by calcite; few Fe-nodules } \\
\text { very few rounded clay } \\
\text { pedorelicts }\end{array}$ \\
\hline c & $\begin{array}{l}\text { Accumulation of } \\
\text { land shells }\end{array}$ & $\begin{array}{l}\text { Scarce quartz and feldspar } \\
\text { grains and few subangular } \\
\text { fragments of limestone in a } \\
\text { silty-clayey matrix }\end{array}$ & $\begin{array}{l}\text { Very abundant to } \\
\text { abundant land snails } \\
\text { and fragments; scarce } \\
\text { to common angular } \\
\text { charcoal fragments; } \\
\text { few phytoliths; very } \\
\text { few weathered vegetal } \\
\text { remains; very few } \\
\text { fragments of coprolites; } \\
\text { shell fragments locally } \\
\text { organized in thin } \\
\text { horizontal layers with } \\
\text { scarce matrix }\end{array}$ & $\begin{array}{l}\text { Common } \\
\text { chambers, channels } \\
\text { and vughs; locally, } \\
\text { packing voids }\end{array}$ & $\begin{array}{l}\text { Crumb to } \\
\text { spongy }\end{array}$ & Cristallitic & $\begin{array}{l}\text { Double spaced } \\
\text { porphyric; locally, } \\
\text { close porphyric }\end{array}$ & $\begin{array}{l}\text { Abundant micrite and } \\
\text { sparite coating on crumbs } \\
\text { and voids; scarce calcite } \\
\text { nodules; groundmass } \\
\text { locally impregnated by } \\
\text { calcite; few excremental } \\
\text { infillings; few Fe-nodules; } \\
\text { very few rounded clay } \\
\text { pedorelicts }\end{array}$ \\
\hline $\begin{array}{l}\text { Transition } \\
\quad \text { from } \\
C \text { to } D\end{array}$ & $\begin{array}{l}\text { Accumulation of } \\
\text { land shells } \\
\text { to calcareous tufa }\end{array}$ & $\begin{array}{l}\text { Alternating micritic and } \\
\text { sparitic layers, including } \\
\text { very few fragments of } \\
\text { limestone and quartz grains }\end{array}$ & $\begin{array}{l}\text { Common to scarce shell } \\
\text { fragments; scarce } \\
\text { angular charcoal } \\
\text { fragments }\end{array}$ & $\begin{array}{l}\text { Mostly fenestral } \\
\text { voids; palnar voids }\end{array}$ & Laminated & Cristallitic & - & - \\
\hline
\end{tabular}


Table 3

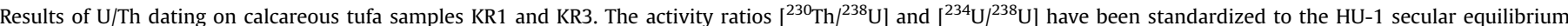

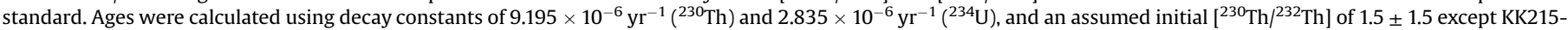
3B, for which a value of 0.8 has been assumed. Depths are from the sample top, and numbers in brackets are the $95 \%$ uncertainties in the last digits given.

\begin{tabular}{|c|c|c|c|c|c|c|c|}
\hline Sample ID & Depth (mm) & ${ }^{238} \mathrm{U}(\mathrm{ng} / \mathrm{g})$ & {$\left[{ }^{234} U /{ }^{238} U\right]( \pm 95 \%)$} & {$\left[{ }^{230} \mathrm{Th} /{ }^{238} \mathrm{U}\right]^{*} 10^{3}( \pm 95 \%)$} & {$\left[{ }^{234} U /{ }^{238} U\right]_{\text {initial }}( \pm 95 \%)$} & Age (ka) & Age corr. (ka) \\
\hline KR3-B & 1 & $348(1.4)$ & $1.0684(0.0009)$ & $4.78(0.6)$ & $1.0695(0.0009)$ & $4.999(0.064)$ & $4.730(0.06)$ \\
\hline KR3-E & 13.3 & - & $1.0637(0.0039)$ & $4.81(0.6)$ & $1.0646(0.0040)$ & $5.029(0.006)$ & $4.820(0.24)$ \\
\hline KR3-D & 45 & - & $1.0645(0.0040)$ & $5.25(0.4)$ & $1.0664(0.0041)$ & $5.495(0.046)$ & $5.174(0.34)$ \\
\hline KR1-E & 45.5 & - & $1.0788(0.0039)$ & $7.62(0.7)$ & $1.0805(0.0040)$ & 7.955(0.075) & $7.700(0.30)$ \\
\hline KR1-A & 97.7 & $272(20)$ & $1.0820(0.0023)$ & $9.31(0.8)$ & $1.0841(0.0023)$ & $9.770(0.09)$ & $8.990(0.83)$ \\
\hline
\end{tabular}

including a well preserved Fasad point (Fig. 5). A sample of charcoal from the Unit B has been dated to $10,040 \pm 50$ uncal BP (11,798-11,311 cal BP). Two radiocarbon dates were obtained on charcoal fragments collected at different levels of the Unit $C$ (Table 1), giving $9150 \pm 50$ uncal BP (Unit B; 10,486-10,226 cal BP) and 9010 uncal BP (Unit C; 10,250-9934 cal BP). Also in the case of site GQ-13/23, a thick flowstone descending from the roof of the shelters (Unit D) seals the whole stratigraphic sequence.

Interesting information can be detected at the micro-scale; thin sections from the infilling of both caves display similar features (Table 2). Thin sections of the clast-supported breccia Units A and B highlight the presence of limestone angular clasts (breccia), probably deriving from thermal degradation of the vault of the rock shelter. The matrix of the breccia consists of sand grains (Unit A) and loess-like (Unit B) sandy silt (increasing in percentage from Unit A to Unit B). The local origin of limestone clasts is confirmed by the occurrence of marine microfossils typical of the rock formations constituting the Jebel Qara (Fig. 6). On the contrary, the intergranular sediments, rich in quartz, feldspar and heavy minerals
(Cremaschi and Negrino, 2005), are unrelated to the local geological context and originated from deflation of the sands from the Nejd desert. At the microscopic scale, the overlaying Unit $C$ includes a high concentration of large fragments of land snails, in some cases broken and distributed in planar layers (Fig. 7). The occurrence of loess sediments as in this unit indicates that the dust supply from the Nejd desert was still active, but the occurrence of pedorelicts due to colluvial processes indicates wetter environmental conditions in comparison with those that drove the formation of the underlying deposit.

\subsection{Flowstone chronology and geochemical analyses}

A total of eight U-series dating have been performed on two samples KR1 and KR3 collected from the same flowstone decoration sealing the base deposits of the KR-213 shelter. Unfortunately, due to the low $U$ content and high level of detrital (Th) contamination, only the results of five out of eight ages can be considered as reliable (Table 3). U/Th ages indicate that flowstone KR1 is basically
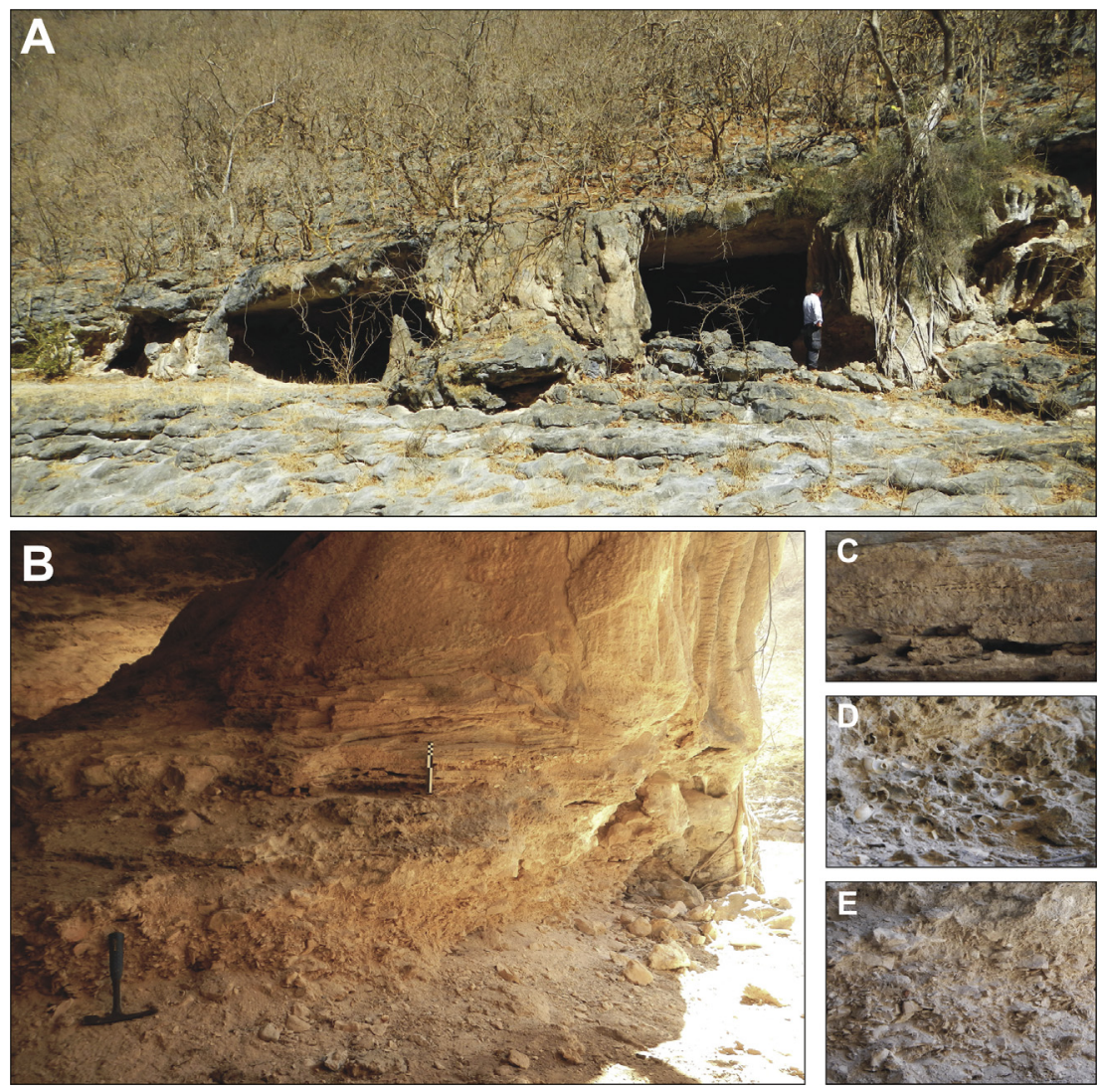

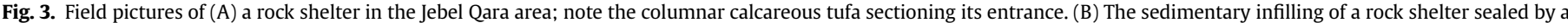

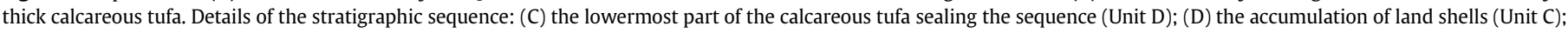
(E) the angular breccia with a loessic matrix (Unit B). 

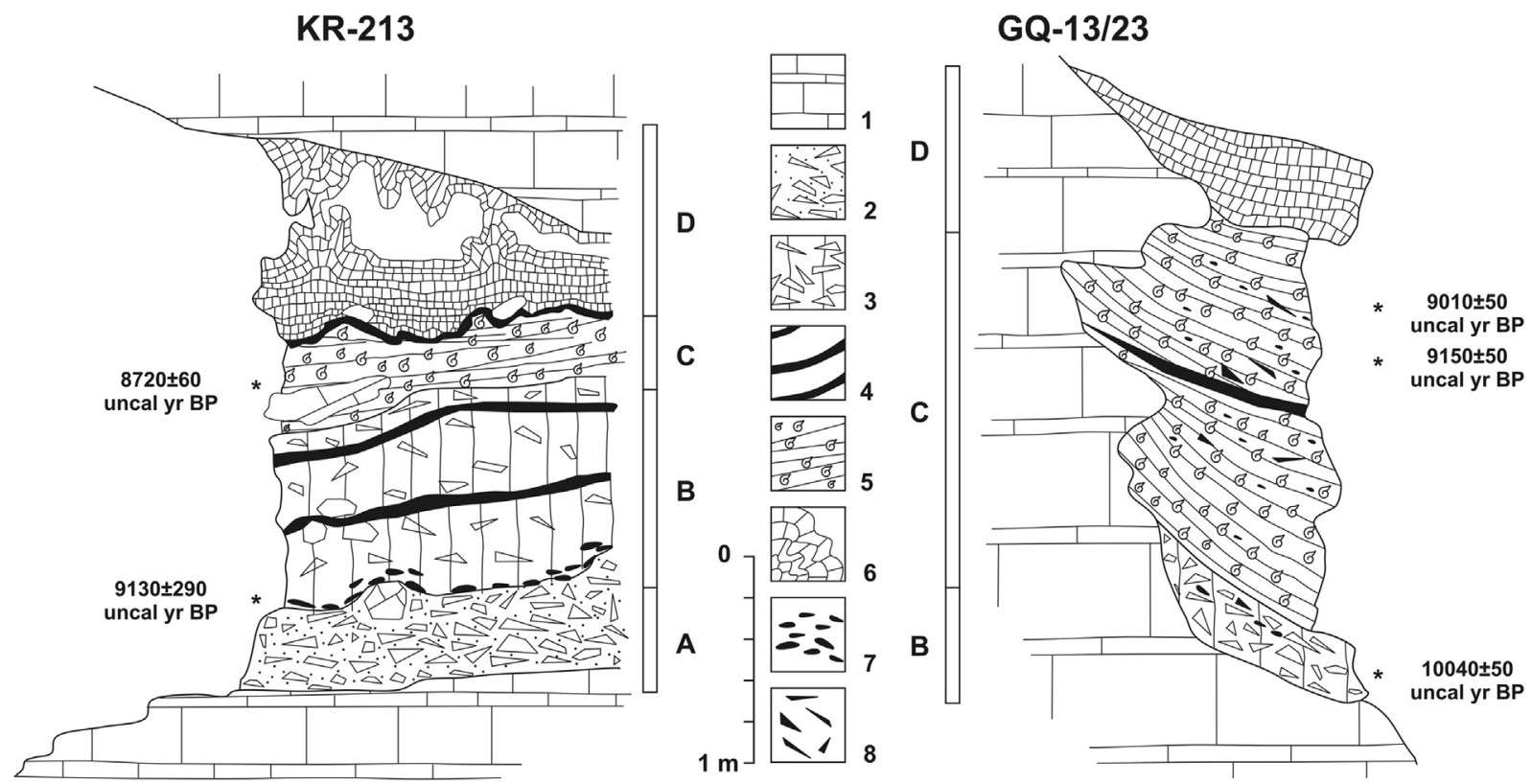

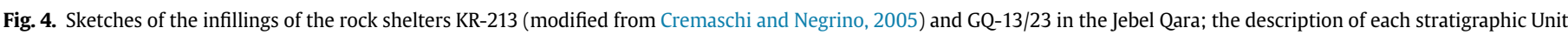

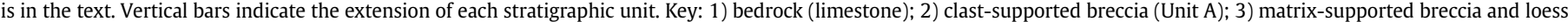
(Unit B); 4) organic matter-rich layers; 5) accumulations of land shells/escargotieres (Unit C); 6) calcareous tufa (Unit D); 7) fragments of charcoal; 8) lithic artefacts.
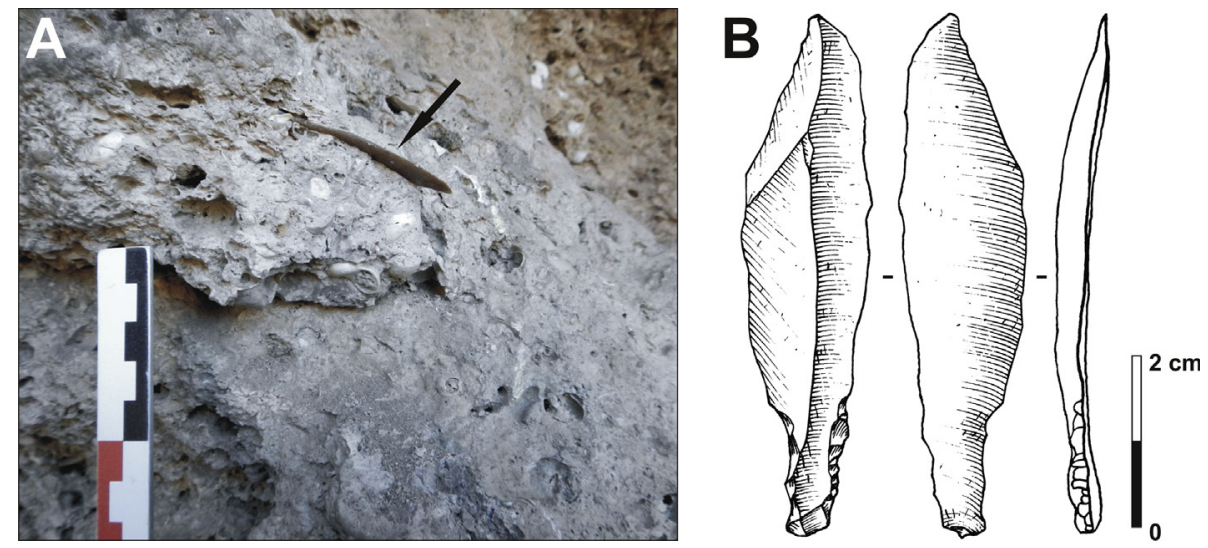

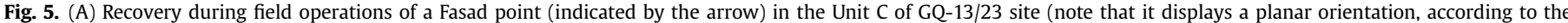
stratigraphy); (B) the drawing of the same item (by. G. Devilder, CNRS).

older than KR3 (Table 3 and Fig. 8); KR1 formed in the Early Holocene between c. 9500 and $7500 \mathrm{BP}$, whereas KR3 precipitated in the Middle Holocene between 5500 and 4500 BP.

Despite this, stable isotopes from both samples show some similarities, which are particularly strong in the top sections, where isotopes (both oxygen and carbon) show significant excursion toward higher values (Figs. 8 and 9). Carbon values range between -12 and -3 and oxygen values are between -2 and 1 . Kinetic fractionation sometimes occurs in cave-entrance speleothems and calcareous tufa (Mickler et al., 2006), but in the present case (Fig. 9) carbon isotopic composition shows a low positive correlation with oxygen record $\left(R^{2}=0.52\right.$ for KR1 and $R^{2}=0.2$ for KR3). In sample KR3 at $\sim 20 \mathrm{~mm}$ from the top, there is a sharp change in texture and fabric, marked by a thin whitish layer, suggesting the possibility of a hiatus. Because this interval is not chronologically constrained, it would correspond to the top of sample KR1. Owing to this uncertainty the upper interval of KR3 at this stage was not further considered. A simple, linear age model was then constructed for both samples; the ages model need considered as largely indicative (Fig. 8).

\subsection{Archaeological content of the deposits}

At GQ-13/23, as previously observed in neighbouring sites and in those located along Wadi Darbat (Cremaschi and Negrino, 2002, 2005), Fasad points are present, attesting to human occupation by hunter-gatherers during the Early Holocene. One point in particular (Fig. 5), which has been collected in situ (in Unit C, dated to $10,486-10,226 \mathrm{yr}$ cal BP), is made on a pointed blade showing a bilateral convergent preparation with the removal of two previous blades creating a Y-shape guiding arises in order to obtain a final pointed blade. This method of blade production is reminiscent of (probably) contemporaneous methods observed in inland Dhofar sites (Hilbert, 2014) or in Hadramawt, Yemen (Crassard, 2008). The Fasad point from GQ-13/23 is $62 \mathrm{~mm}$ long with an abruptretouched tang along about one quarter total length of the piece, being typologically much closer to those specimens found in the area (Cremaschi and Negrino, 2002). More broadly, it has many typological resemblances with other examples known from surface sites in Dhofar and elsewhere in Oman and the United Arab Emirates (Charpentier and Crassard, 2013). Very few lithics have been 

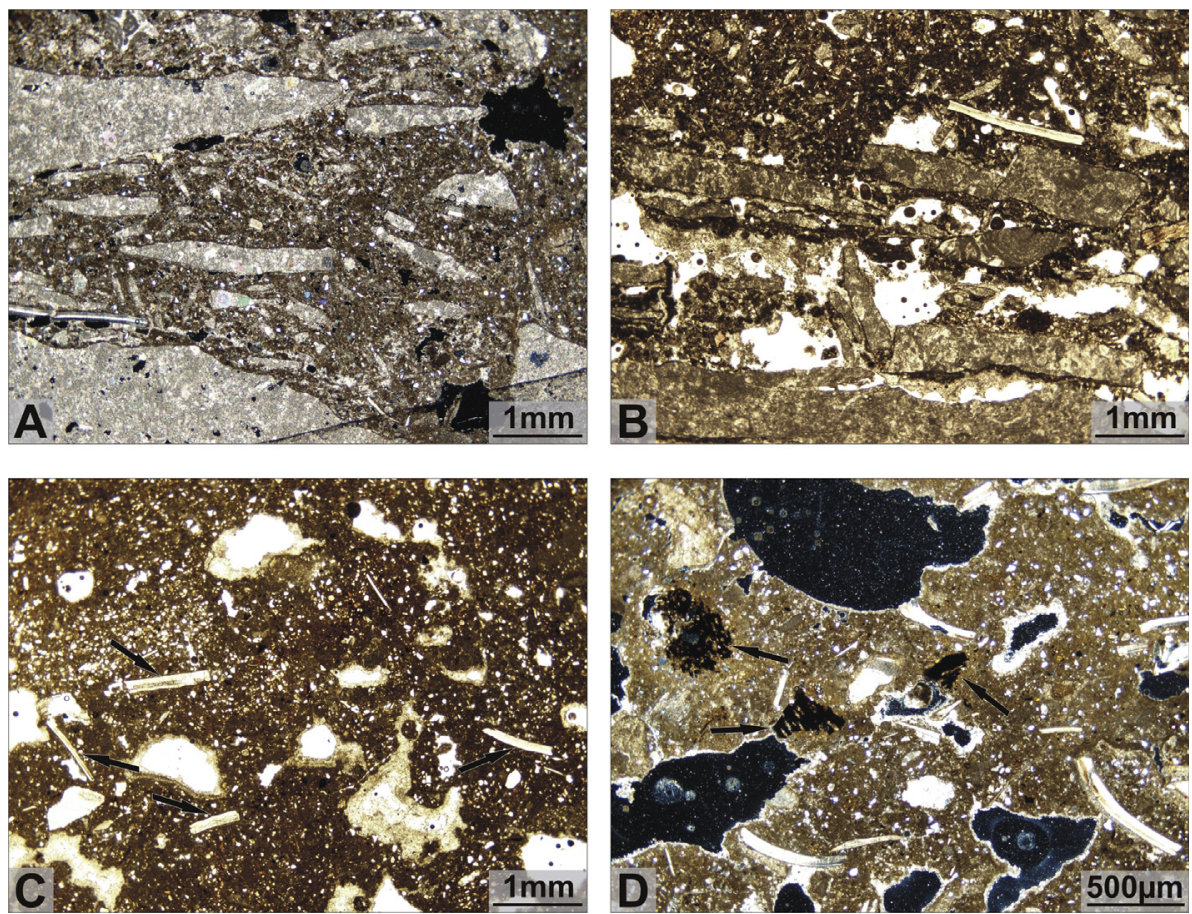

Fig. 6. Photomicrographs of thin sections of the deposits of rock shelter GQ-13/23. (A) Lower part of Unit B, planar orientation of rock fragments forming a matrix-supported angular breccia (XPL). (B) Unit B, transition between a clast to matrix-supported breccia; note the occurrence of micrite pendents on rock fragments (PPL). (C) Unit B, brown silty fine matrix deeply cemented by calcium carbonate with common quartz grains; the arrows indicate small shell fragments (PPL). (D) Upper Unit B, strong redistribution of calcium carbonate cement forming crystalline pedofeatures and enclosing charcoal fragments (indicated by the arrows; XPL).

found in relation to this point at GQ-13/23, making it difficult to propose a precise technological assessment of the complete lithic assemblage. Nevertheless, both type and technology observed on this single artefact at GQ-13/23, confirm the chronological and thus cultural affiliation of this industry to the Early Holocene. However, it is not firmly known, and still highly debated, if the makers of this kind of projectiles have a local origin related to autochthonous Late Palaeolithic groups. As well, it is not known if the occupants at GQ$13 / 23$, and their counterparts in the region who were making these Fasad points, are actually the direct ancestors of the Neolithic populations that rapidly spread inland and along the coasts about two millennia later. Only a complete stratigraphic sequence
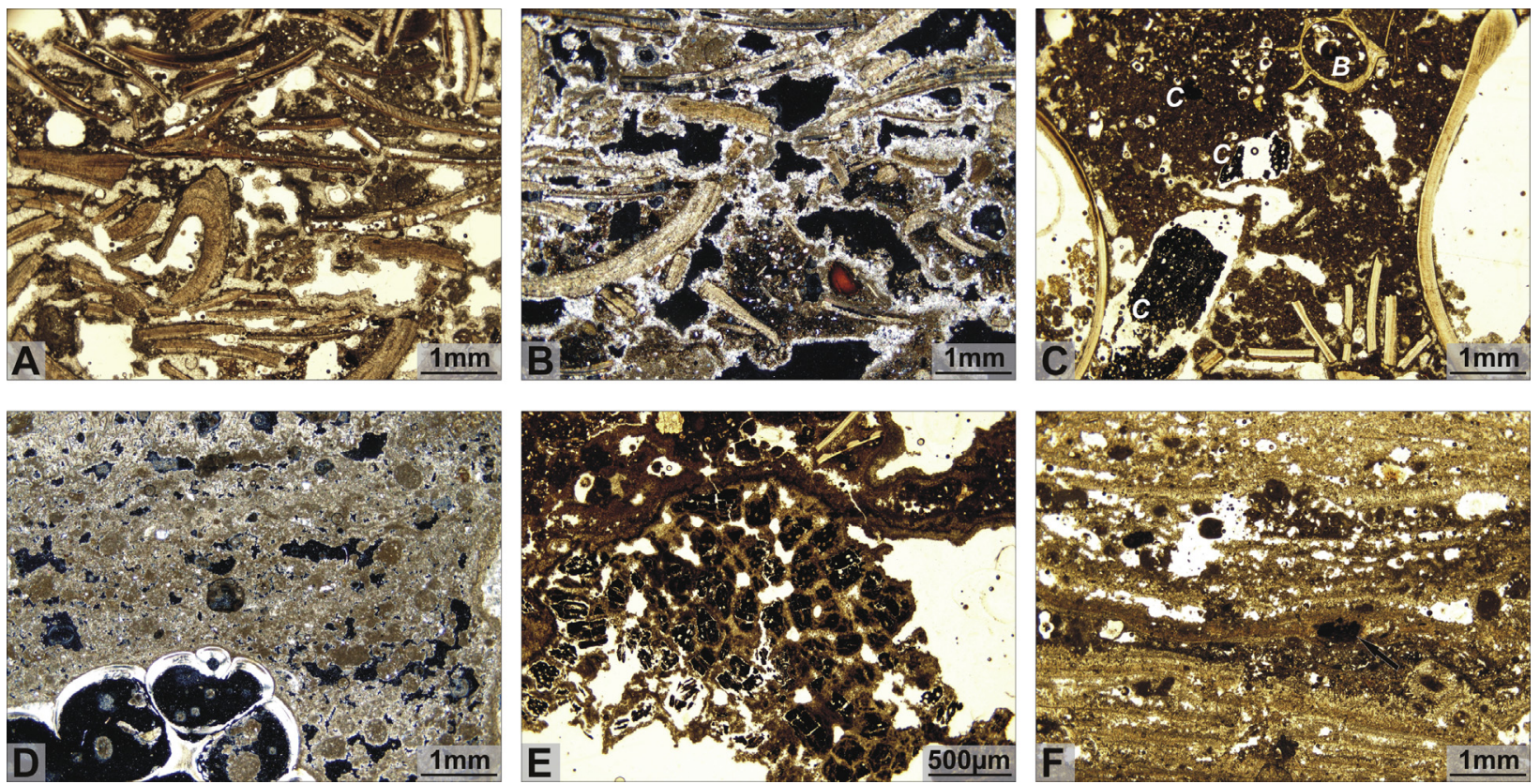

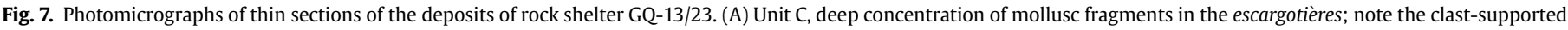

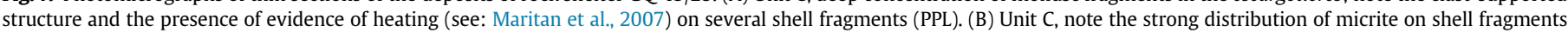

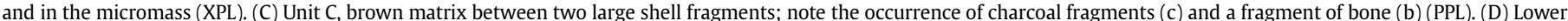

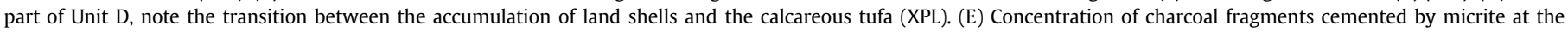
transition between Unit C and Unit D (PPL). (F) Laminated microstructure with common fenestral voids of the calcareous tufa at the basis of Unit D (PPL). 


\section{Flowstone KR1}
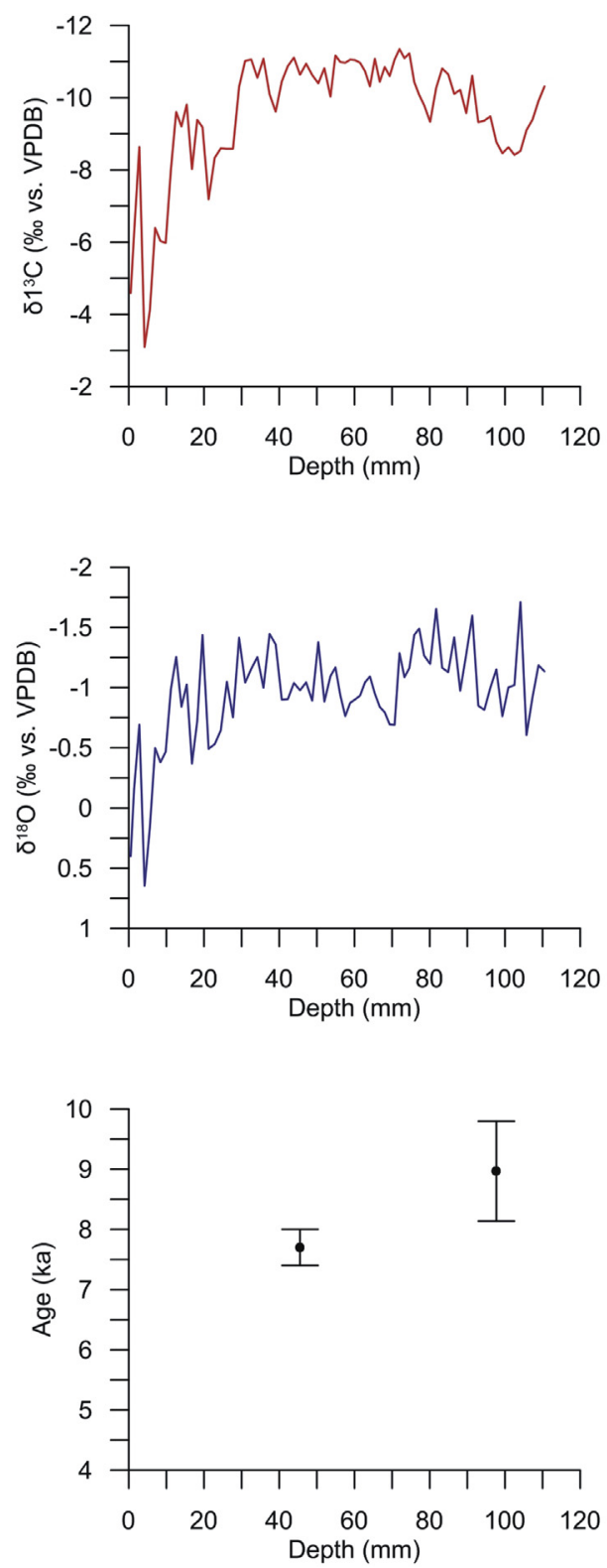

\section{Flowstone KR3}
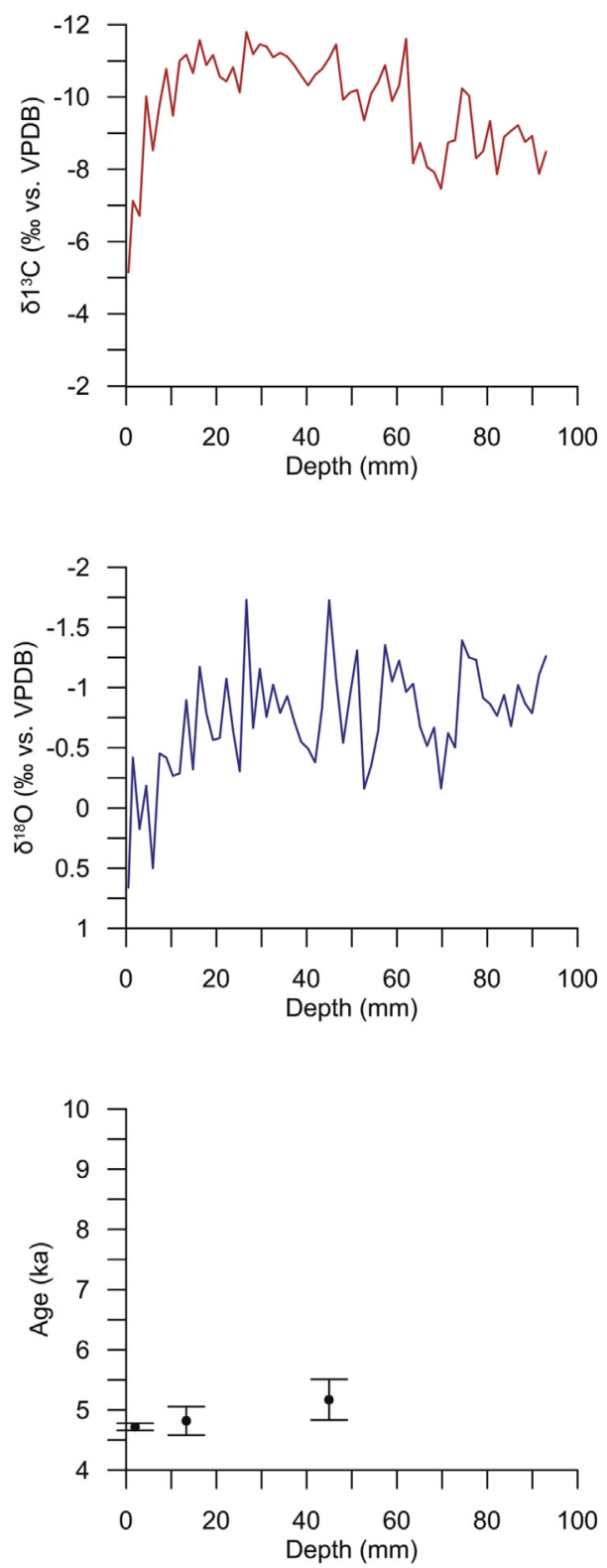

Fig. 8. Isotopic profiles ( $\mathrm{C}$ and $\mathrm{O}$ ) of the considered samples of flowstones (KR1 and KR3) and position of U/Th dating results according to flowstones' depth.

yielding remains of occupations from the Terminal Pleistocene up to the Neolithic period would help in answering such a crucial archaeological issue.

\section{Discussion}

\subsection{Evolution of the climate during the Early and Middle Holocene}

The four different stratigraphic units described in the rock shelters of Jebel Qara permit to trace the Late Quaternary environmental evolution of the massif. The whole sequence ranges from c. $11,798-11,311$ cal BP (calibrated ${ }^{14} \mathrm{C}$ age) to c. 4230 a (U/Th age), including the whole Early and Middle Holocene.

The sedimentary processes leading to the formation of the clastto matrix-supported breccia at the bottom of the stratigraphic sequences appear to be related to thermoclastic shattering of the rocky walls of the cave (Cremaschi and Negrino, 2005) and has to be related to arid climatic conditions. According to the heavy minerals assemblage, aeolian sand and silt included in the fine fraction indicate dust transport by strong northerly winds from the Nejd desert. This phase can be dated to a Late Pleistocene/very Early Holocene dry phase (Sanlaville, 1992; Fleitmann et al., 2004). In the Unit B, the breccia decreases or completely disappears and the loess fraction becomes dominant and may be correlated with the peridesert loess deposits of the same age occurring at the northern fringe of Jebel Qara (Cremaschi and Negrino, 2005), and suggests a phase in which northerly winds are still important. The deposition of peridesert loess in southern Arabian Peninsula was put in relation to slightly humid environmental conditions, allowing the growth of vegetation (herbs and bushes) able to trap dust particles 


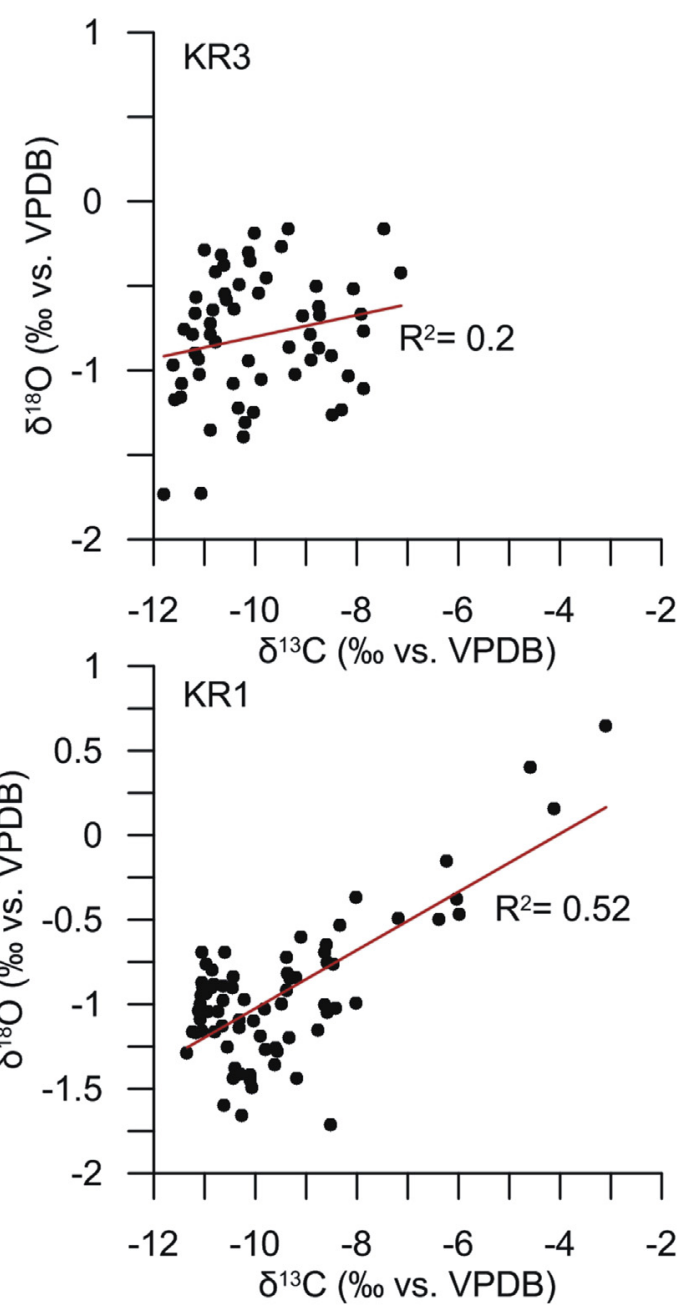

Fig. 9. The cross plots of $\delta^{18} \mathrm{O}$ versus $\delta^{13} \mathrm{C}$ for each sample (Hendy test); the correlation between $\mathrm{C}$ and $\mathrm{O}$ values are also reported.

(Pye, 1987, 1995; Coudé Gaussen, 1991; Wright, 2001). Therefore, the transition between Units A to B occurred under progressively more humid environmental conditions, presumably triggered by the resumption of the Indian Ocean monsoon system and the northward shift of the ITCZ.

The Unit C is mainly characterized by a large content of shells of mesophilous land snails, indicating the spreading of a savannahlike environment; the sedimentation of this Unit has been interpreted (Cremaschi and Negrino, 2005) as a consequence of the onset of wetter conditions in comparison to that of the underlying loess and breccia deposits. While the ecology of the molluscs supports a climatic interpretation, their occurrence in high concentration inside the rock shelters has to be interpreted as due to human activity as it will be discussed in detail in the next section.

A large increase in precipitation intensity is indicated by calcareous tufa, which constitutes Unit D. Their formation was triggered by the progressive reinforcement of the Indian Ocean monsoon system and the northward shift of the ITCZ, which contrasted the northern winds responsible for the sand and loess transport recorded in the underlying units. The stratigraphic sections of the Jebel Qara record progressive increases in the intensity of precipitation towards the calcareous tufa in Unit D. The deposition of freshwater carbonates in arid lands requires a major shift in geomorphologic processes and in climate (e.g., Smith et al., 2004; Cremaschi et al., 2010). Calcareous tufa at Jebel Qara formed since

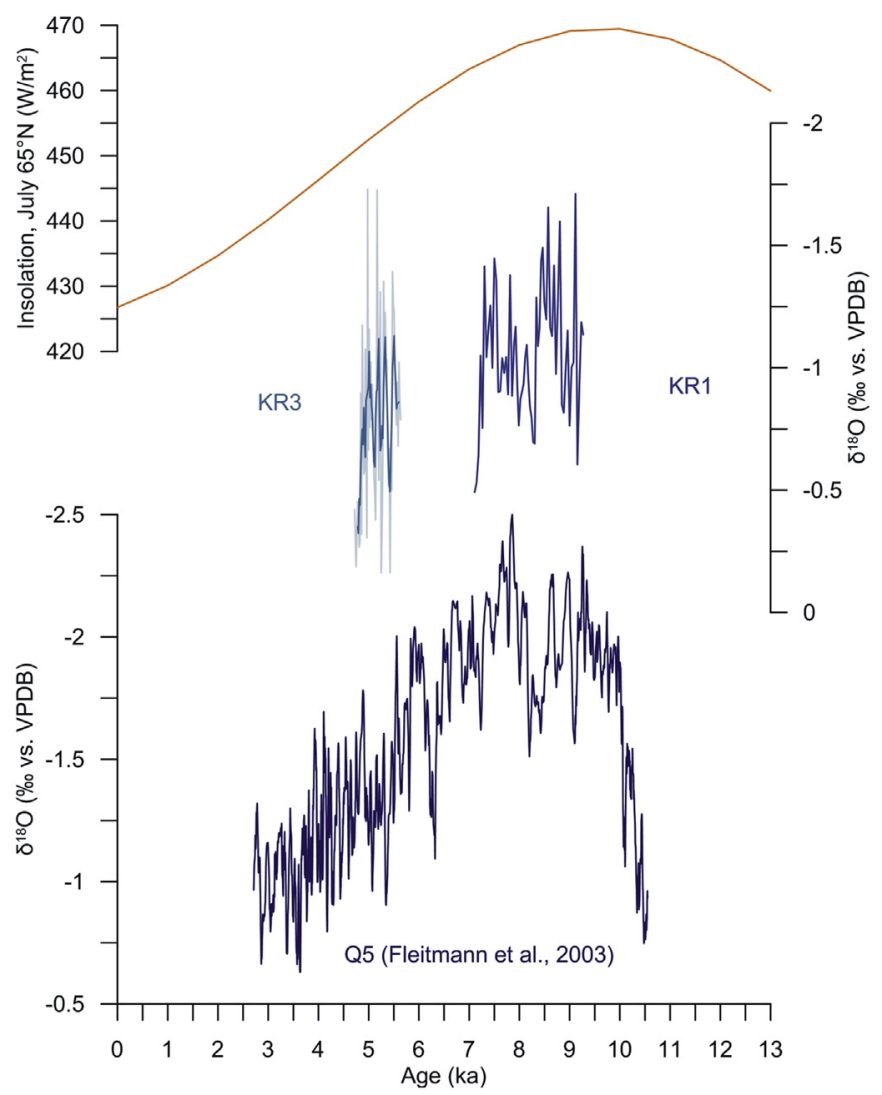

Fig. 10. Composite oxygen isotope profiles of flowstones KR1 and KR3 compared with the oxygen curve of the Q5 site (Qunf cave, southern Oman) elaborated by Fleitmann et al. (2003). Changes in Holocene summer insolation (according to Berger and Loutre, 1991) are also reported.

the beginning of the wet Holocene at c. $9000 \mathrm{BP}$ (U-series age) and survived up to the start of its decline, at the beginning of the late Holocene arid phase (Hoorn and Cremaschi, 2004).

The investigation on the speleothems collected from Unit D offers a more detailed palaeoenvironmental reconstruction. In fact, even though they are generally less laminated and pure than speleothems, cave-entrance calcareous tufa may represent a powerful tool for palaeoenvironmental reconstruction in arid lands (e.g., Smith et al., 2004; Moeyersons et al., 2006; O'Brien et al., 2006; Cremaschi et al., 2010). Following the interpretation reported for speleothem of the area, lower oxygen isotope values indicate higher humidity related (amount effect) to northward displacement of Indian monsoon domain, which occurred at time of higher summer insolation in the northern Hemisphere (Burns et al., 1998; Fleitmann et al., 2003, 2004, 2007, 2011). On the contrary, higher oxygen isotope values are connected to phases of reduced precipitation associated to weakening of the monsoon system and increasing importance of northern, drier winds. The composite record of samples KR1 and KR3 is (up to now) too discontinuous for inferring detailed short term oscillation, but we note that the most negative $\delta^{18} \mathrm{O}$ values were reached at the beginning of the Holocene, suggesting the maximum of precipitation. This was followed by a progressive increase of $\delta^{18} \mathrm{O}$ values, interpreted as a decline in the intensity of the monsoon system. Carbon isotopic compositions show a low positive correlation with oxygen record (Fig. 9); correlation between $\mathrm{C}$ and $\mathrm{O}$ is often interpreted as indicative of kinetic fractionation (Mickler et al., 2006), this can be also driven by climatic effects (Drysdale et al., 2004; Cremaschi et al., 2010). In particular, during drier periods a reduction in soil development can 
produce effects such as decreasing in soil productivity and decreasing recharge promoting, for instance prior calcite precipitation (e.g., Genty et al., 2003; Drysdale et al., 2006). These processes can produce increasing carbon isotopic composition along with higher oxygen isotope values due to decreasing monsoon strength. The apparent significant increase in both oxygen and carbon isotope composition at the top of both samples may indicate the progressive obsolescence of the flow preannouncing the end of calcite deposition, which would have been occurred for the definitive reduction in water recharge due to climate condition.

In our study, independent control is made by comparison (Fig. 10) with Holocene speleothem from Oman as discussed by Burns et al. (1998) and Fleitmann et al. (2003, 2004, 2007, 2011). The range of oxygen isotope values measured in our flowstones partially overlaps the values measured in cave speleothems from northern and southern Oman (Fleitmann et al., 2004, 2007). Arguably, this is a good indication of the potential of these flowstones to preserve important hydrological information despite their high superficiality, which often can promote isotopic kinetic fractionation. Moreover, the composite record of samples KR1 and KR3 is evidently similar to Fleitmann's record from the Q5 speleothem (Fig. 10). Notably, the $\delta^{18} \mathrm{O}$ record of sample KR3 is lower than the KR1, but is in agreement with the general trend of speleothems from site Q5. Finally, in sample KR1 the end of deposition can be roughly constrained at ca. $7.5 \mathrm{ka} \mathrm{BP}$, when the Q5 speleothem shows a clear monotonic increasing of $\delta^{18} \mathrm{O}$ values.

At the regional scale, in the Early and Middle Holocene the southern Arabia experienced a generalized increasing of environmental humidity (e.g., Lézine et al., 1998; Neff et al., 2001; Fleitmann et al., 2004; Parker et al., 2004), triggered by the intensification of the monsoonal precipitation as a consequence of an enhanced solar heating across the northern Hemisphere (Berger and Loutre, 1991; Sirocko et al., 1993; Gasse and Van Campo, 1994). This span has been identified as a major phase of a permanent lacustrine environment in the Rub' al-Khali sand sea and in the arid regions of Yemen (e.g., McClure, 1976; Schultz and Whitney, 1986; Parker et al., 2004; Lézine et al., 2007; Parker, 2009).

Finally, it is interesting to take into account the work of Lézine et al. (2007) on the response of a freshwater environment of the Ramlat as-Sab'atayn sand sea in continental Yemen to the increase of the Indian monsoon strength. Their archive shows a maximum of Holocene water availability at c. $9000-8000$ cal BP, as in the whole region; but it also highlights some differences with respect to the highly detailed record of precipitation from speleothems (Fleitmann et al., 2003). At Ramlat as-Sab'atayn the initial increase of monsoon precipitation is dated from c. 12,000 cal BP (radiocarbon dating on freshwater mollusc), whereas due to the necessity to the recharge of the mountain aquifers the sedimentation of speleothems started later. In the Jebel Qara this phase corresponded to the beginning of loess sedimentation and therefore, according to our interpretation, to the initial spread of vegetation able to trap dust particle as a consequence of enhanced precipitation. This possibly confirms that the strengthening of the Indian Ocean monsoon started at the very beginning of the Holocene.

\subsection{Early Holocene human occupation of the cavities Jebel Qara}

Evidence of human occupation (lithic industry and charcoal) in the cavities of Jebel Qara is mostly concentrated in the Unit C, apart from the occasional find of charcoal in Unit B, and it is systematically associated with high concentration of mollusc shells. At the macroscopic scale, molluscs and archaeological evidence occur only in the cavities located in the valley floors of easy accessibility. On the contrary in the caves and shelters, hanging at different heights along the steep valley slopes, molluscs and artefacts are absent and calcareous tufa directly overly Units A and B. Inside the cave deposits molluscs are associated with organic layers, charcoal, and in some case to small fragments of burnt bones and to lithic artefacts. In thin section, the evidence of human activity is clearer as shells of land snail are often broken and redistribute in flat layers with planar distribution of clasts and associated to finely subdivided organic matter and charcoal lenses; these are indicative for occupational trampling (e.g., Gé et al., 1993; Zerboni, 2011). Moreover, the micromorphological investigation of the mollusc rich strata showed, in some cases, evidence for heating of shells, represented by peculiar interference colours and pores within the shell microstructure (see Maritan et al., 2007). Archaeological features similar to those observed at Jebel Qara have been recently described at the micro-scale by Balbo et al. (2010) and Zerboni (2011); due to the many analogies with them, we interpreted the shells layers inside the studied rock shelters as intentional accumulations related to human activities. The land snails-bearing layers occurring in the rock shelters of the Jebel Qara have to be interpreted as anthropic accumulation of land shells or escargotières (sensu Lubell et al., 1976).

The lithic assemblages associated to these sites, including laminar debitage, sometimes Fasad points, represent the remains of hunter gathers populations (Charpentier, 2008; Charpentier and Crassard, 2013). Nevertheless, the identification of accumulations of land snails at Jebel Qara represents an unprecedented evidence of foraging strategy adopted by the Early Holocene human groups in southern Arabia. The frequentation of the area was made possible thanks to a main climatic shift towards wet conditions, in contrast with the aridity that dominated in the area at the transition between the Late Pleistocene and the Early Holocene. New and wetter environmental conditions promoted the ecological settings suitable to the development of the molluscs fauna of the Jebel Qara, representing another type of food resources for these populations. At present, we have no evidence for any kind of connection between the Early Holocene sites of Jebel Qara and the coastal area, as for example no marine shell has been found in the inland sites. Along the coast, sites of that age are extremely rare, as one single cave site has been discovered so far dated to the Early Holocene: the Natif 2 site at about $100 \mathrm{~km}$ to the East (publication in preparation).

After this phase, the increasing of the Indian Ocean monsoon system and the northward shift of the ITCZ, which was in charge of the formation of calcareous tufa, made the rock shelters at the southern margin of the Jebel Qara unsuitable for life and consequently they were abandoned. During the phase characterized by the most wet environmental conditions at Jebel Qara (between $c$. 8000 and 5000 cal BP), the occurrence of many shell middens distributed along the coast of central Oman (e.g., Biagi and Nisbet, 1992, 2006; Biagi, 1994, 2005, 2013; Berger et al., 2013) suggests that later prehistoric groups shifted from the mountains to coastal Oman. Therein, they exploited the resources rendered available by the formation of the mangroves, which was triggered by the oscillations of the level of the sea, but also enhanced thanks to the input of freshwater from inland due to reinforced monsoon rain (Lézine et al., 2002; Berger et al., 2005, 2013).

\section{Conclusions}

The infilling of caves and rock shelters of Jebel Qara gave the opportunity to reconstruct the climate changes that occurred in the area during the Early to Middle Holocene and to confirm previous regional studies. Furthermore, the geoarchaeological investigations allowed the discovery of peculiar and unprecedented strategy for the exploitation of natural resources performed by the Early Holocene hunter gatherers. 
The stratigraphic record represented in the Jebel Qara rock shelters indicates that during this time the climate of the area changed from dry conditions, dominated by northern winds, to a wet climate, which was on the contrary dominated by the southern monsoon system, and back again to progressively drier conditions. Our evidence is substantially in accordance with data from the caves of Oman (Fleitmann et al., 2007), which indicate a northward advance of the latitudinal position of the ITCZ (and increased monsoonal precipitation) in the period 10,500-9500 cal BP, a part of the beginning of monsoon reinforcement, which possibly started some centuries before, as confirmed for instance by Lézine et al. (2007). We can find a good correlation also with the beginning of the withdrawn of the summer monsoon (and southward migration of the ITCZ), which began since c. 7800 cal BP and reached its maximum at c. $3500 \mathrm{cal} \mathrm{BP}$, in response to the decreasing of solar heating (Hoorn and Cremaschi, 2004; Fleitmann et al., 2007). Also in the case of Jebel Qara, the palaeoenvironmental archive suggests a progressive weakening of the intensity of the Indian monsoon, rather than its abrupt interruption.

After the arid climate at the Pleistocene/Holocene transition, from c. 10,500 to 9500 cal BP the climatic conditions became more humid, probably in relation with the shift of the monsoon front in a closer position to the Dhofar coast; ecological conditions in this period were favourable to a large development of land mollusc fauna and the land snails were exploited as a food resource by human groups, which settled the rock shelters opening at the wadi bottom. After that, since c. 9000 cal BP the enhanced intensity of the monsoon system led to the formation of calcareous tufa and the cavities of Jebel Qara were abandoned and the later prehistoric groups were attracted by other regions. They possibly moved to the coastal plain of Salalah, but the Neolithic archaeological record indicates intensive occupations along the coast of central Oman; therein they exploited the resources rendered available in the mangroves, whose development was favoured by the inland expansion of the monsoon rains.

\section{Acknowledgements}

We thank the organizers of the Green Arabia conference in Oxford, and especially Prof. Michael Petraglia, for inviting us to present these results. We wish to thank the archaeological authorities of the Sultanate of Oman, especially Dr. Sultan Al-Bakri, director of the Department of Excavations and Archaeological Studies, and Prof. Maurizio Tosi, Ministry of Heritage and Culture, the Salalah MHC branch and its welcoming staff, as well as the French Embassy in Oman. VC wishes to thank the 'Consultative Commission for Excavations Abroad' of the Ministry of Foreign Affairs, for granting the expedition since 2010. RC wishes to thank the Fondation Fyssen (Paris) for the 'Subvention de Recherche 2013' grant that greatly contributed to the sedimentological, speleothems and cave filling analyses, radiocarbon and U/Th dating, as well as logistical expenses on the field. For tremendous help on the field, we wish to thank Ali al-Ma'ashani and Federico Borgi, and the welcoming and helpful people of Jebel Qara.

\section{References}

Balbo, A.L., Madella, M., Vila, A., Estévez, J., 2010. Micromorphological perspectives on the stratigraphical excavation of shell middens: a first approximation from the ethnohistorical site Tunel VII, Tierra del Fuego (Argentina). Journal of Archaeological Science 37, 1252-1259.

Berger, A., Loutre, M.F., 1991. Insolation values for the climate of the last 10 million years. Quaternary Science Reviews 10, 297-317.

Berger, J.F., Cleuziou, S., Davtian, G., Cattani, M., Cavulli, F., Charpentier, V., Cremaschi, M., Giraud, J., Marquis, P., Martin, C., Méry, S., Plaziat, J.-C., Saliège, J.F., 2005. Évolution paléographique du Ja'alan (Oman) à l'Holocène moyen: impact sur l'évolution des paleomilieux littoraux et les strategies d'adaptation des communautés humaines. Paléorient 31 (1), 46-63.

Berger, J.F., Charpentier, V., Crassard, R., Martin, C., Davtian, G., Lopez-Saez, J.A. 2013. The dynamics of mangrove ecosystem, changes in sea level and the strategies of Neolithic settlements along the coast of Oman (6000-3000 cal BC). Journal of Archaeological Science 40, 3087-3104.

Biagi, P., 1994. A radiocarbon chronology for the aceramic shell-middens of coastal Oman. Arabian Archaeology and Epigraphy 5, 17-31.

Biagi, P., 2013. The shell middens of Las Bela coast and the Indus delta (Arabian Sea, Pakistan). Arabian Archaeology and Epigraphy 1-6.

Biagi, P., Nisbet, R., 1992. Environmental history and plant exploitation at the aceramic sites of RH5 and RH6 near the mangrove swamp of Qurum (Muscat e Oman). Bulletin de la Société Botanique Française 139, 571-578.

Biagi, P., Nisbet, R., 2006. The prehistoric fisher-gatherers of the western coast of the Arabian Sea: a case of seasonal sedentarization? World Archaeology 38, $220-238$

Biagi, P., 2005. The shell-middens of the Arabian Sea and Gulf: maritime connections in the seventh millennium BP? In: Al-Ansary, A.R., et al. (Eds.), The City in the Arab World: Evolution and Development, pp. 7-16.

Bullock, P., Fedoroff, N., Jongerius, A., Stoops, G., Tursina, T., Babel, U., 1985. Handbook for Soil Thin Section Description. Waine Research Publication, Albrighton, ST, USA.

Burns, S.J., Matter, A., Frank, N., Mangini, A., 1998. Speleothem-based paleoclimate record from northern Oman. Geology 26, 499-502.

Charpentier, V., 2004. Trihedral points: a new facet to the "Arabian Bifacial Tradition". In: Proceedings of the Seminar for Arabian Studies, 34, pp. 53-66.

Charpentier, V., 2008. Hunter-gatherers of the "empty quarter of the early Holocene" to the last Neolithic societies: chronology of the late prehistory of southeastern Arabia (8000-3100 BC). Proceedings of the Seminar for Arabian Studies $38,59-82$.

Charpentier, V., Crassard, R., 2013. Back to Fasad... and the PPNB controversy. Questioning Levantine origin in Arabian Early Holocene projectile points technology. Arabian Archaeology and Epigraphy 24 (1), 28-36.

Coque-Delhuille, B. Gentelle, P. 1998. Aeolian dust and superficial formations in the arid part of Yemen. In: Alsharhan, A.S., Glennie, K.W., Whittle, G.L., Kendall, C. (Eds.), Quaternary Deserts and Climate Change. Balkema, Rotterdam, pp. 199-208.

Coudé-Gaussen, G. 1991. Les poussières sahariennes. John Libbey Eurotext, Rome.

Courty, M.A., 2001. Microfacies analysis assisting archaeological stratigraphy. In: Goldberg, P., Holliday, V.T., Ferring, C.R. (Eds.), Earth Sciences and Archaeology. Kluver Academic/Plenum Publishers, New York, pp. 205-239.

Crassard, R., 2008. The "Wa'shah method": an original laminar debitage from Hadramawt, Yemen. Proceedings of the Seminar for Arabian Studies 38, 3-14.

Crassard, R., 2009. Modalities and characteristics of human occupations in Yemen during the Early/Mid-Holocene. Comptes rendues Geoscience 341, 713-725.

Cremaschi, M., Negrino, F., 2002. The frankincense road of Sumhuram: palaeoenvironmental and prehistorical background. In: Avanzini, A. (Ed.), Khor Rori Report 1. Edizioni Plus, Pisa, pp. 325-363.

Cremaschi, M., Negrino, F., 2005. Evidence for an abrupt climatic change at $870014 \mathrm{C}$ yr B.P. in Rockshelters and Caves of Gebel Qara (Dhofar-Oman): palaeoenvironmental implications. Geoarchaeology: An International Journal 20, 559-579.

Cremaschi, M., Perego, A., 2008. Patterns of land use and settlements in the surroundings of Sumhuram. An intensive geo-archaeological survey at Khor Rori: report of field season February 2006. In: Avanzini, A. (Ed.), A Port in Arabia between Rome and the Indian Ocean (3rd c. BC-5th c. AD) Khor Rori Report 2. Erma di Bretschneider, Rome, pp. 563-573.

Cremaschi, M., Zerboni, A., Spötl, C., Felletti, F., 2010. The calcareous tufa in the Tadrart Acacus Mt. (SW Fezzan, Libya). An early Holocene palaeoclimate archive in the central Sahara. Palaeogeography, Palaeoclimatology, Palaeoecology 287, $81-94$.

Cremaschi, M., Zerboni, A., Mercuri, A.M., Olmi, L., Biagetti, S., di Lernia, S., 2014. Takarkori rock shelter (SW Libya): an archive of Holocene climate and environmental changes in the central Sahara. Quaternary Science Reviews 101, 36-60.

Davies, C., 2006. Quaternary paleohydrology and past climates of the Dhamar Highlands. Yemen. Quat. Res. 66, 454-464.

Drysdale, R.N., Zanchetta, G., Hellstrom, J., Fallick, A.E., Zhao, J., Isola, I., Bruschi, G., 2004. The palaeoclimatic significance of a Middle to late Pleistocene stalagmite from the Alpi Apuane karst, central-western Italy. Earth and Planetary Science Letters 227, 215-229.

Drysdale, R.N., Zanchetta, G., Hellstrom, J., Maas, R., Fallick, A.E., Pickett, M., Cartwright, I., Piccini, L., 2006. Late Holocene drought responsible for the collapse of Old World civilizations is recorded in an Italian cave flowstone. Geology 34, 101-104.

Fleitmann, D., Burns, S.J., Mudelsee, M., Neff, U., Kramers, J., Mangini, A., Matter, A., 2003. Holocene forcing of the Indian monsoon recorded in a stalagmite from southern Oman. Science 300, 1737-1739.

Fleitmann, D., Burns, S.J., Neff, U., Mudelsee, M., Mangini, A., Matter, A., 2004. Palaeoclimatic interpretation of high-resolution oxygen isotope profiles derived from annually laminated speleothems from Southern Oman. Quaternary Science Reviews 23, 935-945.

Fleitmann, D., Burns, S.J., Mangini, A., Mudelsee, M., Kramers, J., Villa, I., Neff, U., AlSubbary, A.A., Buettner, A., Hippler, D., Matter, A., 2007. Holocene ITCZ and Indian monsoon dynamics recorded in stalagmites from Oman and Yemen (Socotra). Quaternary Science Reviews 26, 170-188. 
Fleitmann, D., Burns, S.J., Pekala, M., Mangini, A., Al-Subbary, A., Al-Aowah, M., Kramers, J., Matter, A., 2011. Holocene and Pleistocene pluvial periods in Yemen, southern Arabia. Quaternary Science Reviews 30, 783-787.

Gasse, F., Van Campo, E., 1994. Abrupt post-glacial climate events in West Asian and North Africa monsoon domains. Earth and Planetary Science Letters 126, 435-456.

Gé, T., Courty, M.-A., Matthews, W., Wattez, J., 1993. Sedimentary formation processes of occupation surfaces. In: Goldberg, P., Nash, D.T., Petraglia, M.D. (Eds.), Formation Processes in Archaeological Context, Monographs in World Archaeology 17. Prehistory Press, Madison, WI, pp. 149-163.

Genty, D., Blamart, D., Ouahdi, R., Gilmour, M., Baker, A., Jouzel, J., Van-Exter, S., 2003. Precise dating of Dansgaard-Oeschger climate oscillations in western Europe from stalagmite data. Nature 421, 833-837.

Goldberg, P., Macphail, R.I., 2006. Practical and Theoretical Geoarchaeology. Blackwell Publishing, Oxford.

Hanna, S., Al-Belushi, M., 1996. Introduction to the Caves of Oman. Sultan Qaboos University, Ruwi.

Hellstrom, J.C., 2003. Rapid and accurate U/Th dating using parallel ion-counting multicollector ICP-MS. Journal of Analytical Atomic Spectrometry 18, 1346-1351.

Hilbert, Y.H., 2013. Khamseen rock shelter and the Late Palaeolithic-Neolithic transition in Dhofar. Arabian Archaeology and Epigraphy 24 (1), 51-58.

Hilbert, Y.H., 2014. Khashabian, a Late Paleolithic Industry from Dhofar, Southern Oman. In: BAR International Series 2601. Archaeopress, Oxford.

Hoorn, C., Cremaschi, M., 2004. Late Holocene palaeoenvironmental history of Khawr Rawri and Khawr Al Balid (Dhofar, Sultanate of Oman). Palaeogeography, Palaeoclimatology, Palaeoecology 213, 1-36.

Lézine, A., Saliège, J., Robert, C., Wertz, F., Inizan, M., 1998. Holocene lakes from Ramlat as-Sab'atayn (Yemen) illustrate the impact of monsoon activity in southern Arabia. Quaternary Research 50, 290-299.

Lézine, A.M., Saliège, J.-F., Mathieu, R., Tagliatela, T.L., Méry, S., Charpentier, V., Cleuziou, S., 2002. Mangroves of Oman during the late Holocene: climatic implications and impact on human settlements. Vegetation History and Archaeobotany $11,221-232$.

Lézine, A., Tiercelin, J.J., Robert, C., Saliège, J.F., Cleuziou, S., Inizan, M.L., Braemer, F., 2007. Centennial to millennial-scale variability of the Indian monsoon during the Early Holocene from a sediment, pollen and isotope record from the desert of Yemen. Palaeogeography, Palaeoclimatology, Palaeoecology 243, 235-249.

Lubell, D., Hassan, F.A., Gautier, A., Ballais, J.-L., 1976. The Capsian escargotières. Science 191, 910-920.

Maritan, L., Mazzoli, C., Freestone, I., 2007. Modelling changes in mollusc shell internal microstructure during firing: implications for temperature estimation in shell-bearing pottery. Archaeometry 49, 529-541.

McClure, H.A., 1976. Radiocarbon chronology of late Quaternary lakes in the Arabian Desert. Nature 263, 755-756.

Mickler, P.J., Stern, L.A., Banner, J.L., 2006. Large kinetic isotope effects in modern speleothems. Geological Society of America Bulletin 118, 65-81.

Moeyersons, J., Nyssen, J., Poesen, J., Deckers, J., Haile, M., 2006. Age and backfill/ overfill stratigraphy of two tufa dams, Tigray Highlands, Ethiopia: evidence for Late Pleistocene and Holocene wet conditions. Palaeogeography, Palaeoclimatology, Palaeoecology 230, 165-181.

Murphy, C.P., 1986. Thin Section Preparation of Soils and Sediments. AB Academic Publishers, Berkhamsted, Herts.

Neff, U., Burns, S.J., Mangini, A., Mudelsee, M., Fleitmann, D., Matter, A., 2001. Strong coherence between solar variability and the monsoon in Oman between 9 and 6 kyr ago. Nature 411, 290-293.

Nettleton, W.D., Chadwick, O.A., 1996. Late Quaternary redeposited loess-soil development sequences, South Yemen. Geoderma 70, 21-36.

O'Brien, G.R., Kaufman, D.S., Sharp, W.D., Atudorei, V., Parnell, R.A., Crossey, L.J., 2006. Oxygen isotope composition of annually banded modern and midHolocene travertine and evidence of paleomonsoon floods, Grand Canyon, Arizona, USA. Quaternary Research 65, 366-379.

Parker, A.G., 2009. Pleistocene climate change in Arabia: developing a framework for hominin dispersal over the last $350 \mathrm{ka}$. In: Petraglia, M.D., Rose, J.I. (Eds.), The Evolution of Human Populations in Arabia, Vertebrate Paleobiology and Paleoanthropology, 39. Springer Science + Business Media B.V, pp. 39-49.

Parker, A.G., Eckersley, L., Smith, M.M., Goudie, A.S., Stokes, S., Ward, S., White, K., Hodson, M.J., 2004. Holocene vegetation dynamics in the northeastern Rub' alKhali desert, Arabian peninsula: a phytolith, pollen and carbon isotope study. Journal of Quaternary Science 19 (7), 665-676.

Parker, A.G., Wilkinson, T.J., Davies, C., 2006. The early-mid Holocene period in Arabia: some recent evidence from lacustrine sequences in eastern and southwestern Arabia. Proceedings of the Seminar for Arabian Studies 36, 243-255.
Pietsch, D., Kühn, P., 2009. Soil developmental stages of layered Cambisols and Calcisols on Socotra Island, Yemen. Soil Science 174, 292-302.

Pietsch, D., Kühn, P., Brunner, U., Scholten, T., Hitgen, H., Gerlach, I., 2010. Holocene soils and sediments around Ma'rib Oasis, Yemen. Further Sabaean treasures? The Holocene 20, 785-799.

Pirazzoli, P.A., 1991. World Atlas of Holocene Sea-level Changes. Elsevier Oceanography Series, Amsterdam.

Platel, J.P., 1992. Geological Map of Salalah (Sheet NE 40-09), Explanatory Notes. Sultanate of Oman Ministry of Petroleum and Minerals, Orleans.

Platel, J.P., Berthiaux, A., Le Metour, J., Beurier, M., Roger, J., 1992. Geological Map of Juzor Al Halaaniyaat (Sheet NE 10-10). Directorate General of Minerals, Oman Ministry of Petroleum and Minerals, Muscat.

Preusser, F., Radies, D., Matter, A., 2002. A 160 ka record of dune development in Southern Arabia and atmospheric circulation patterns. Science 296, 2018-2020. Pye, K., 1987. Aeolian Dust and Dust Deposits. Academic, London.

Pye, K., 1995. The nature, origin and accumulation of loess. Quaternary Science Reviews 14, 653-667.

Regattieri, E., Zanchetta, G., Drysdale, R.N., Isola, I., Hellstrom, J.C., Roncioni, A., 2014. A continuous stable isotopic record from the Penultimate glacial maximum to the Last Interglacial (160 to $121 \mathrm{ka}$ ) from Tana Che Urla Cave (Apuan Alps, central Italy). Quaternary Research 82, 450-461.

Reimer, P.J., Bard, E., Bayliss, A., Beck, J.W., Blackwell, P.G., Bronk Ramsey, C. Buck, C.E., Edwards, R.L., Friedrich, M., Grootes, P.M., Guilderson, T.P., Haflidason, H., Hajdas, I., Hatté, C., Heaton, T.J., Hoffman, D.L., Hogg, A.G. Hughen, K.A., Kaiser, K.F., Kromer, B., Manning, S.W., Niu, M., Reimer, R.W., Richards, D.A., Scott, M., Southon, J.R., Staff, R.A., Turney, C.S.M., van der Plicht, J., 2013. INTCAL13 and MARINE13 radiocarbon age calibration curves 0-50,000 years cal BP. Radiocarbon 55, 1869-1887.

Rogers, T.D., 1980. Meteorological records from the mountain region of Dhofar. The scientific results of the Oman flora and fauna survey 1977 (Dhofar). Journal of Oman Studies, Special Report 2, 55-58.

Sale, J.B., 1980. The environment of the mountain region of the Dhofar. The scientific results of the Oman flora and fauna survey 1977 (Dhofar). Journal of Oman Studies, Special Report 2, 17-24.

Sanlaville, P., 1992. Changements climatiques dans la Péninsule Arabique durant le Pléistocène Supérieur et l'Holocène. Paléorient 18, 5-26.

Shtober-Zisu, N., Amasha, H., Frumkin, A., 2015. Inland notches: implications for subaerial formation of karstic landforms-an example from the carbonate slopes of Mt. Carmel, Israel. Geomorphology 229, 85-99.

Schultz, E., Whitney, J.W., 1986. Upper Pleistocene and Holocene lakes in the An Nafud, Saudi Arabia. Hydrobiologia 143, 175-190.

Sirocko, F., Sarthein, M., Erlenkeuser, H., Lange, H., Arnold, M., Duplessy, J.-C., 1993. Century-scale events in monsoonal climate over the past 24,000 years. Nature 364, 322-324.

Smith, J.R., Giegengack, R., Schwarcz, H.P., 2004. Constraints on Pleistocene pluvial climates through stable-isotope analysis of fossil-spring tufas and associated gastropods, Kharga Oasis, Egypt. Palaeogeography, Palaeoclimatology, Palaeoecology 206, 157-175.

Stoops, G., 2003. Guidelines for Analysis and Description of Soil and Regolith Thin Sections. Soil Science Society of America, Madison, WI.

Stoops, G., Marcellino, V., Mees, F., 2010. Interpretation of Micromorphological Features of Soil and Regoliths. Elsevier, Amsterdam.

Uerpmann, H.-P., Uerpmann, M., Kutterer, A., Jasim, S.A., 2009. The Neolithic period in the central region of the Emirate of Sharjah (UAE). Arabian Archaeology and Epigraphy 24 (1), 102-108.

Wilkinson, T.J., 1997. Holocene environments of the high plateau, Yemen. Recent archaeological investigations. Geoarchaeology 12, 833-864.

Wright, C.A., 1963. The freshwater gastropod molluscs of Western Aden Protectorate. Bulletin of the British Museum of Natural History 10, 254-274.

Wright, J.S., 2001. "Desert” loess versus "glacial” loess: quartz silt formation, source areas and sediment pathways in the formation of loess deposits. Geomorphology 36, 231-256.

Wright, C.A., Brown, D.S., 1980. The freshwater mollusca of Dhofar. Journal of Oman Studies, Special Report 2, 97-102.

Zarins, J., 2001. The Land of Incense: Archaeological Work in the Governorate of Dhofar, Sultanate of Oman, 1990-1995. Sultan Qaboos University Publications, Muscat.

Zarins, J., 2013. Hailat Araka and the South Arabian Neolithic. Arabian Archaeology and Epigraphy 24 (1), 109-117.

Zerboni, A., 2011. Micromorphology reveals in situ Mesolithic living floors and archaeological features in multiphase sites in central Sudan. Geoarchaeology: An International Journal 26, 365-391. 